\title{
How do most low ETR firms avoid paying taxes?
}

\author{
Dane M. Christensen ${ }^{1} \cdot$ David G. Kenchington ${ }^{2}$ (1) $\cdot$ Rick C. Laux $^{3}$ (1)
}

Accepted: 14 June 2021/Published online: 10 September 2021

(C) The Author(s), under exclusive licence to Springer Science+Business Media, LLC, part of Springer Nature 2021

\begin{abstract}
Evidence suggests a large proportion of profitable U.S. firms have low effective tax rates (i.e., an ETR between 0 and 10\%). Despite widespread interest in how firms avoid paying taxes, we do not know how most firms attain low ETRs and whether they are primarily benefiting from benign or aggressive tax positions. Using a research design that explicitly examines low ETR firms, we predict and find that the majority are primarily benefiting from a benign tax position: large net operating loss carryforwards (NOLs). We also find that large NOLs allow firms to persistently retain low ETRs year after year. In contrast, we find that multinationals and tax haven firms, which should have more opportunities for aggressive tax planning, have a lower probability of attaining a low ETR (relative to domestic and non-tax haven firms). Collectively, these findings suggest that the typical low ETR firm does not incur significant tax risk. Consistent with this, we find that low ETR firms accrue unrecognized tax benefits at a similar rate as firms that pay the statutory tax rate and do not experience higher future tax rate volatility. Overall, the results shed light on the profile of the average low ETR firm and provide evidence that the majority are utilizing large NOLs rather than aggressive tax planning.
\end{abstract}

Keywords Taxes $\cdot$ Net operating loss carryforwards $\cdot$ Tax risk $\cdot$ Political economy

JEL classification $\mathrm{H} 26 \cdot \mathrm{G} 38 \cdot \mathrm{M} 41$

David G. Kenchington

David.Kenchington@asu.edu

Dane M. Christensen

DaneC@uoregon.edu

Rick C. Laux

RickLaux@purdue.edu

Extended author information available on the last page of the article 


\section{Introduction}

Recent studies document that a large proportion of profitable U.S. firms have effective tax rates (ETRs) far below the statutory tax rate. ${ }^{1}$ For instance, Dyreng et al. (2008) find that roughly one out of five firms has an annual cash ETR of less than 10\%. Similarly, the Institute on Taxation and Economic Policy (ITEP) finds that around 20\% of large firms have an ETR of less than 10\% (Gardner et al. 2017). And the U.S. Government Accountability Office (2016) documents that about $20 \%$ of large firms paid no federal income taxes in 2012. Given the evidence that a large number of firms attain such low ETRs, a natural question arises: How are they doing it?

One plausible explanation is that low ETR firms are engaging in aggressive tax planning. Numerous academic studies provide evidence consistent with this explanation. $^{2}$ Notably, Dyreng et al. (2019) find that, on average, firms with relatively lower ETRs bear greater tax risk than firms with higher ETRs. Similarly, the media, policymakers, and public interest groups frequently portray low ETR firms as "tax dodgers" that use accounting gimmicks to push the envelope of tax law. For instance, the business press is replete with headlines about how multinational firms avoid paying taxes by shifting billions in profits offshore to tax havens. ${ }^{3}$ Likewise, politicians, such as Senator Bernie Sanders, argue: "There is something profoundly wrong in America when one out of five profitable corporations pay nothing in federal income taxes.... Corporate greed is destroying the fabric of America. It must come to an end."4

While it is intuitive to link firms with low ETRs to aggressive tax planning, there is also evidence that raises questions about how prevalent aggressive strategies really are. Specifically, De Simone et al. (2019) find that, rather than shifting profits out of the United States, the majority of multinational firms report net inbound payments from their foreign subsidiaries. Similarly, Blouin and Robinson (2020) provide evidence that studies have significantly overstated the magnitude of tax-motivated profit shifting, because they use data that double counts foreign profits. ${ }^{5}$ And Guenther et al. (2017, p. 133) find that low ETRs tend to be persistent and ETRs are not negatively associated with future tax rate volatility, which is "... most consistent with the idea that low ETRs reflect the extent to which a firm's operations allow the firm to take advantage of benign tax-favored transactions as opposed to differences in managers' willingness to reduce the firm's tax payments through risky tax positions."

Given the alternative interpretations of how firms attain low ETRs, we argue that we still have a very limited understanding of this group of firms. That is, while there is an

\footnotetext{
${ }^{1}$ Hereafter we use the term "firm" to refer to profitable firm-years of U.S. corporations, unless stated otherwise.

2 See Balakrishnan et al. (2019); Hasan et al. (2014); Donohoe and Knechel (2014); Chyz et al. (2013); Rego and Wilson (2012); Kim et al. (2011); Chen et al. (2010).

${ }^{3}$ See The Economist (2013, 2018); Drucker (2010); Chew (2016); Torry (2014); Drucker and Bowers (2017).

${ }^{4}$ See Sanders (2016). For other examples by policymakers and public interest groups, see Levin and McCain (2013); Joint Committee on Taxation (2010); Gravelle (2015); and Phillips et al. (2017).

${ }^{5}$ In addition, the ITEP study discussed above suggests that just 30 Fortune 500 companies account for nearly $70 \%$ of the estimated $\$ 2.6$ trillion of accumulated offshore profits. Further, the largest sample of tax shelters examined in the literature is just a few hundred firms, and, due to enforcement, the incidence of tax shelters has sharply declined since the turn of the century (Lisowsky et al. 2013).
} 
extensive literature on cross-sectional differences in ETRs, studies generally focus on average ETRs and thus cannot directly speak to how a firm ends up in the left-tail of the ETR distribution. Similarly, even though there is plenty of evidence that large multinational firms engage in aggressive tax planning, we do not know whether that is an accurate profile of the majority of low ETR firms. Consequently, in this study, we examine how most firms attain low ETRs (i.e., an ETR between 0 and 10\%).

We predict that the majority of profitable firms that attain a low ETR are primarily benefiting from a benign tax position: large net operating loss carryforwards (NOLs). We make this prediction for three reasons. First, the costs of achieving a low ETR are likely to be high for firms using aggressive tax positions but negligible for firms utilizing large NOLs. A fundamental principle of the Scholes and Wolfson framework (Scholes et al. 2015) is that firms will reduce their ETRs as long as the marginal benefits exceed the marginal costs. In the case of aggressive tax planning, firms must weigh the increased tax savings with the potential costs, such as implementation and concealment costs, potential fines and penalties, auditor scrutiny (Donohoe and Knechel 2014; Hoopes et al. 2012), reduced corporate transparency (Desai and Dharmapala 2006; Balakrishnan et al. 2019), agency costs (Chen et al. 2010), increased borrowing costs (Hasan et al. 2014), and reputational concerns (Graham et al. 2014). Since prior research provides evidence that these costs can be significant, they are likely to constrain many firms from realizing a low ETR through aggressive tax planning.

In contrast, firms with large NOLs need not weigh the increased tax savings with the potential costs. Since using large NOLs is not a choice but a result of prior poor performance, large NOLs simply allow firms to reduce their ETRs with no material costs or risk of the position being overturned by tax authorities. As a result, large NOL firms do not face the same potential costs of tax planning as firms without large NOLs and thus should have a greater likelihood of attaining a low ETR.

Second, there is evidence that the tax savings attributable to NOLs can be substantial. For example, a recent study by the Treasury Inspector General for Tax Administration (2015) estimates that firms have accumulated roughly \$2 trillion in Federal NOLs alone as of 2012.

Third, there is a direct link between NOLs and ETRs. In particular, NOLs reduce cash taxes paid and thus result in a lower cash ETR. Further, as we discuss in detail later, the utilization of large NOLs is typically accompanied by a reversal of the valuation allowance, which leads to a lower GAAP ETR.

Collectively, these reasons suggest that the majority of firms that attain a low ETR are likely benefiting from large NOLs. To be clear, while it is well documented that NOLs reduce average ETRs, the nature of our question is very different. It is not obvious from prior research whether the majority of firms that attain low ETRs are primarily benefiting from aggressive tax planning or large NOLs.

To perform our tests, we construct a sample of profitable firm-years for the time period 1994-2014. To identify firms with low ETRs, we create an indicator variable that equals one if a firm has an ETR between 0 and $10 \%$ and zero otherwise. We use $10 \%$ as the cutoff, as this is the threshold used in the influential study by Dyreng et al. (2008) to identify firms with the lowest ETRs. Consistent with prior research that suggests a large proportion of firms have low ETRs, we find that approximately $25 \%$ $(10 \%)$ of our sample have low annual cash (GAAP) ETRs, and roughly 16\% (12\%) have low long-run three- (five-) year cash ETRs. 
To identify firms with large NOLs, we use an intuitive proxy based on whether a firm reports an accumulated deficit on its balance sheet (i.e., negative retained earnings). This measure identifies firms that suffered heavy losses in prior years and classifies roughly $25 \%$ of our sample as large NOL firms. We also corroborate our results using another proxy for large NOLs based on the predicted NOL benefit constructed by Heitzman and Lester (2020). These proxies overcome the severe measurement error in Compustat NOL data (Heitzman and Lester 2020; Kinney and Swanson 1993; Mills et al. 2003) and allow us to answer our research question.

We begin our empirical analysis with a set of univariate tests. First, we calculate the probability that a firm with large NOLs will be included in the low ETR group. We find that firms with large NOLs are roughly four (12) times more likely than firms without large NOLs to have a low annual cash (GAAP) ETR. To put these findings into perspective, we calculate the probability that multinational firms and multinationals with a subsidiary in a tax haven (i.e., haven firms) have a low ETR. Multinationals and, in particular, haven firms are often assumed to have more opportunities for aggressive tax planning (e.g., income shifting) and have been shown to have lower average ETRs than purely domestic and non-haven firms (Rego 2003; Dyreng and Lindsey 2009). However, we find that multinational (haven) firms have a significantly lower probability of attaining a low ETR than domestic (non-haven) firms.

In our second univariate test, we examine the subsample of low ETR firms and simply count the number that have large NOLs. We find that the majority of low ETR firms have large NOLs. In particular, while large NOL firms only constitute a quarter of our sample, we find they comprise $57 \%$ (78\%) of firms with a low annual cash (GAAP) ETR. Similarly, large NOL firms comprise 58\% (56\%) of firms with a low three- (five-) year cash ETR. In contrast, we find that while multinational (haven) firms are more common in our sample than large NOL firms, they comprise only $29 \%$ (23\%) of firms with a low annual cash ETR and 21\% (16\%) with a low annual GAAP ETR. Collectively, our univariate tests suggest that most low ETR firms are primarily benefiting from large NOLs.

We then conduct multivariate tests that examine the probability that a firm with large NOLs will attain a low ETR after controlling for other typical firm characteristics examined in the literature. In these tests, we continue to find that large NOL firms are roughly three (six) times more likely than firms without large NOLs to have a low annual cash (GAAP) ETR. Our inferences are also similar using long-run cash ETRs. Further, similar to our univariate tests, we continue to find that multinational (haven) firms have a lower probability of attaining a low ETR than domestic (non-haven) firms. ${ }^{6}$

To provide further evidence that our results are attributable to large NOLs, we also examine how firms with large NOLs are dispersed across the distribution of ETRs. If

\footnotetext{
${ }^{6}$ To further corroborate these analyses, we perform numerous additional tests outlined in detail in the internet appendix. For example, we show the results are stronger when firm profits are more likely to be in the same jurisdiction as the large NOLs. The results also hold (1) for both large and small firms (i.e., S\&P 1500 and non-1500), (2) using entropy balancing, (3) with firm fixed effects, (4) in every single year of our sample, and (5) using Compustat NOL data. To further address identification, we use the bursting of the Dot.com bubble and the financial crisis as shocks that caused firms to suffer heavy losses and generate large NOLs. Using a difference-in-differences design, we show that in the years following these shocks, the firms most heavily affected by the shocks were more likely to attain low ETRs.
} 
large NOLs are helping firms attain low ETRs, we expect that firms with large NOLs are more likely to be concentrated in lower, rather than higher, portions of the ETR distribution. ${ }^{7}$ Consistent with our expectation, in both univariate and multivariate tests, we find that firms with large NOLs are more likely to be concentrated in lower portions of the ETR distribution. In addition, we find that multinational (haven) firms have a higher probability of reporting an ETR between $10 \%$ to $30 \%$ and are overrepresented in the $10 \%$ to $30 \%$ ETR range, relative to domestic (non-haven) firms.

Overall, the results shed light on the profile of the average low ETR firm and provide evidence that the majority are utilizing large NOLs rather than aggressive tax planning. Since there is a link between tax aggressiveness and tax risk (Blouin 2014), this finding has implications for the relation between low ETRs and tax risk. Recent studies provide conflicting evidence regarding whether low ETR firms incur significant tax risk. For instance, Dyreng et al. (2019) find that firms with lower cash ETRs recognize larger additions in unrecognized tax benefits (UTBs), suggesting that, as firms engage in more tax avoidance, they incur more tax risk. In contrast, Guenther et al. (2017) find that firms with lower ETRs do not have higher future tax rate volatility and interpret the finding as suggesting that low ETRs are likely driven by benign tax positions.

Our finding that the majority of low ETR firms are primarily benefiting from large NOLs (i.e., a benign tax position) suggests that, on average, low ETR firms do not incur significant tax risk. To test this prediction, we first examine whether large NOLs allow firms to persistently retain a low ETR year after year. If large NOLs allow firms to persistently retain a low ETR, then these firms need not engage in aggressive tax planning that results in additions in UTBs, and they are unlikely to experience future tax rate volatility. We find that low ETRs are indeed more persistent for firms with large NOLs, compared to firms without large NOLs, over a five-year period. Further, we find that low ETR firms accrue UTBs at a similar rate as firms that pay roughly the statutory tax rate (i.e., low tax risk firms). Likewise, we find that low ETR firms have future tax rate volatility that is similar to firms that pay roughly the statutory tax rate. Finally, we also provide evidence that the relation between ETRs and tax risk is nonlinear, so the differences in Dyreng et al. (2019) and Guenther et al. (2017) can be largely attributed to how the models are specified. Taken together, the tests provide consistent evidence that low ETR firms generally do not incur significant tax risk.

This study contributes to our understanding of how profitable firms attain low ETRs. The business press, public interest groups, policymakers, and academics are interested in firms with the lowest ETRs. Yet we argue that little is known about this group of firms since studies typically examine variation in average ETRs. By using a research design that explicitly examines low ETR firms, we provide evidence that suggests the majority are benefiting from large NOLs rather than aggressive tax planning. This finding is consistent with the notion that the costs of aggressive strategies constrain firms from attaining low ETRs through aggressive tax planning. In addition, our study contributes to an emerging literature that examines the association between low ETRs and tax risk (Guenther et al. 2017; Dyreng et al. 2019; Guenther et al. 2019). We provide evidence that low ETR firms,

\footnotetext{
${ }^{7}$ Some firms with large NOLs may still pay some income taxes. Reasons for this include (1) limitations on NOL utilization when calculating the alternative minimum tax, (2) firms may not have NOLs in all jurisdictions where they have taxable income, and (3) limitations on NOL utilization under I.R.C. $\S 382$.
} 
on average, do not incur more tax risk than firms that pay roughly the statutory tax rate. Collectively, these findings revise how we think about low ETR firms.

Our findings also complement recent work by Henry and Sansing (2018) and Drake et al. (2020). Henry and Sansing (2018) find that, by adding loss firms to a sample of profit firms, the average firm in the overall population does not appear to be taxfavored. Drake et al. (2020) provide evidence that valuation allowances related to priorperiod losses explain almost the entire downward trend in average ETRs over the last 20 years for profitable domestic firms. However, neither study provides empirical evidence that explains how profitable firms attain low ETRs (i.e., 0 to 10\%). In contrast, our paper provides empirical evidence that large NOLs are a primary way that profitable firms attain a low ETR.

Lastly, it is important to note that our study should not be interpreted as suggesting that firms do not engage in aggressive tax planning. It is well documented that firms do lower their ETRs through aggressive tax planning, and our study is not intended to refute this evidence. Rather, our findings suggest that the use of large NOLs appears to be the more common way for firms to attain low ETRs.

\section{Background and empirical prediction}

\subsection{Prior research and background on net operating losses}

The literature typically defines tax avoidance as any position that reduces the firm's explicit tax liability. ${ }^{8}$ Hanlon and Heitzman (2010) and Lisowsky et al. (2013) elaborate on this definition by suggesting that tax avoidance should be viewed as a continuum that spans from benign tax positions on the left (e.g., investments in municipal bonds) to more aggressive tax positions on the right (e.g., tax sheltering). Lisowsky et al. (2013) further add that the cash and GAAP ETRs typically examined by the business press, public interest groups, policymakers, and academics capture tax positions across the entire tax avoidance continuum.

This leads to the primary question addressed in this study: How do most profitable firms with low ETRs avoid paying taxes? That is, are most firms that attain low ETRs engaging in aggressive tax planning or are most simply benefiting from the tax rules as explicitly intended by legislation?

There is evidence consistent with both views in the tax literature. On the one hand, numerous studies provide evidence that can be interpreted as suggesting that low ETR firms are likely engaging in aggressive tax planning that would fall somewhere on the right side of the tax avoidance continuum. ${ }^{9}$ For example, Dyreng et al. $(2019,179)$ state: "Our expectation is that, on average, as firms engage in greater levels of tax

\footnotetext{
${ }^{8}$ Lisowsky et al. (2013) describe that, under the U.S. tax reporting system, a firm assesses its tax liability and files a tax return showing how it calculated the liability. Following Lisowsky et al. (2013), we refer to any item reported on these tax returns as tax positions.

9 There is no consensus in the tax literature as to where specific tax positions fall on the tax avoidance continuum (Blouin 2014). In this study, we take the stance that positions such as tax shelters, income shifting across jurisdictions, and the use of complex financial instruments are typically riskier and fall somewhere on the more aggressive side of the continuum. In contrast, we believe that the deduction for NOLs falls on the benign end of the tax avoidance continuum.
} 
avoidance [measured using cash ETRs] they will use strategies that involve increasing levels of tax uncertainty." "I0 Indeed, the authors find that firms with cash ETRs in the lowest tercile face significantly greater tax uncertainty. In addition, Balakrishnan et al. (2019, p. 49) express that: “... firms with unusually low tax liabilities [measured using cash and GAAP ETRs relative to industry peers] can be considered more tax aggressive." Consistent with their prediction, they find that firms with lower ETRs have lower corporate transparency, which is consistent with these firms engaging in aggressive tax planning that increases financial and organizational complexity. And Kim et al. (2011, p. 640) suggest: “... a very low level of LRETR [long run cash ETR] likely captures extreme cases of tax sheltering activities such as Enron's." The authors then provide evidence that firms with lower cash ETRs have a higher probability of incurring a future stock price crash, which they interpret as suggesting that more aggressive tax planning facilitates managerial rent extraction and the hoarding of bad news. ${ }^{11}$

On the other hand, recent evidence also suggests that firms with low ETRs may be using more benign tax positions than previously realized. Specifically, Guenther et al. (2017) find that low ETRs are more persistent than high ETRs and that ETRs are not negatively associated with future tax rate volatility. The authors interpret the findings as evidence that lower ETRs, on average, reflect a firm's ability to take advantage of benign tax-favored investments that are unlikely to be challenged by tax authorities. Moreover, Guenther et al. (2019) provide evidence that higher rates of tax avoidance are not riskier than lower rates of tax avoidance, as reflected by increases in UTBs. The authors interpret the findings as suggesting that differences in the rates of tax avoidance are more likely a function of firm characteristics that facilitate tax avoidance than differences in managers' willingness to engage in risky tax positions. With that said, Guenther et al. (2017) and Guenther et al. (2019) do not provide evidence of the specific tax positions that firms are using to attain a low ETR without incurring additional tax risk.

Given the alternative interpretations of extant research, understanding specifically how the majority of low ETR firms avoid paying taxes is an empirical question. ${ }^{12} \mathrm{We}$ believe the answer to this question involves net operating losses, which arise when a firm has negative income for tax purposes. Tax law around the world has long treated negative and positive income asymmetrically. That is, while positive income is subject to immediate taxation, negative income is not necessarily subject to an immediate tax refund. Rather, taxable income is truncated at zero in the year the net operating loss is

\footnotetext{
${ }^{10}$ There is also no consensus in the tax literature as to the relation between tax uncertainty and tax risk. For instance, Dyreng et al. (2019, p. 182) state: "While precise definitions of these constructs are not yet agreed upon in the literature, it is clear that risk, uncertainty, and aggressiveness are related, at least in the tax realm (Blouin 2014)." In this study, we define tax risk as the likelihood that a firm will have to make future tax payments related to current period tax positions, and we also use uncertain tax benefits as a measure of tax risk. Consistent with Blouin (2014), tax risk increases as a tax position becomes more aggressive.

11 There are numerous other examples of tax studies that can be interpreted as suggesting that firms are engaging in aggressive tax planning (e.g., Hasan et al. 2014; Chyz et al. 2013; Rego and Wilson 2012).

12 Dyreng et al. (2017) examine the time trend in ETRs and suggest that researchers also know very little about how ETRs evolve over time. In response to this question, recent research provides evidence that the decline in multinational firm's ETRs arises from a combination of increasing tax benefits from international operations, losses, and declining ETR effects from state taxes, while the decline in domestic firm's ETRs over time can be attributed to losses and changes in the valuation allowance (Henry and Sansing 2018; Drake et al. 2020). In this study, we are interested in cross-sectional differences in how firms attain low ETRs.
} 
generated, and the firm must carry forward the net operating loss (i.e., NOL) to offset taxes to be paid in the future. ${ }^{13}$ If a firm suffers heavy or continued losses, large NOLs can arise and dramatically reduce ETRs when firms subsequently become profitable.

\subsection{Empirical prediction}

We predict that the majority of profitable firms that attain a low ETR are primarily benefiting from large NOLs, rather than from aggressive tax planning. We expect this for at least three reasons. First, the costs of achieving a low ETR are likely to be high for firms using aggressive tax planning but negligible for firms utilizing large NOLs. Prior research suggests that, as firms engage in aggressive tax planning, they must trade off the marginal tax savings with the marginal costs (Scholes et al. 2015). These marginal costs can be significant and include such things as implementation and concealment costs, potential fines and penalties, agency costs (Chen et al. 2010), reduced corporate transparency (Desai and Dharmapala 2006; Balakrishnan et al. 2019), increased borrowing costs (Hasan et al. 2014), auditor scrutiny (Donohoe and Knechel 2014), and increased tax uncertainty (Dyreng et al. 2019). Indeed, surveys of tax executives find that many firms pass on aggressive tax strategies if they perceive that the costs - including reputational concerns and the threat of a tax audit - are too high (Hoopes et al. 2012; Graham et al. 2014). Thus it is likely that many firms will not be able to reduce their ETR as much as they desire before the marginal costs exceed the marginal benefits.

In contrast, firms using large NOLs do not need to trade off the marginal tax savings with the marginal costs. Since using large NOLs is not a choice, but a result of prior poor performance, large NOLs simply allow firms to reduce their ETRs with no material costs or risk of the position being overturned by tax authorities. As a result, firms with large NOLs do not face the same potential costs of tax planning as firms without large NOLs and thus should have a greater likelihood of attaining a low ETR.

Second, the deduction for NOLs can have a material impact on the tax burden of a large number of firms. For example, using corporate tax return data available from the Internal Revenue Service (IRS) Statistics of Income (SOI) program for the years 19942013, we estimate that roughly one-third of profit firms used NOLs to completely eliminate their U.S. tax liability (untabulated).

Third, as we discuss in detail in the internet appendix, there is a direct link between the deduction for NOLs and the ETRs typically examined in the literature. For instance, the utilization of NOLs reduces cash taxes paid and thus results in a lower cash ETR. Additionally, since the carryforward period for NOLs extends well beyond one year in most jurisdictions, large NOLs can also reduce long-run cash ETRs. Further, the

\footnotetext{
${ }^{13}$ During our sample period, firms could also carry back net operating losses to offset taxes paid in the past. However, the carryback period was limited to between two and five years in the United States, while losses could be carried forward up to 20 years. After our sample period, the Tax Cuts and Jobs Act was passed, making it so that most U.S. corporations could only carry net operating losses forward (indefinitely), although the recent Coronavirus Aid, Relief, and Economic Security (CARES) Act allows five-year carrybacks for losses incurred in 2018, 2019, or 2020. NOL carrybacks do not directly affect our inferences, because they only affect ETRs in the first year a loss is recognized, and loss years are not included in our sample. Further, we do not believe carrybacks will have a major effect on our proxies for large NOLs, because studies, such as Cooper and Knittel (2006), suggest the vast majority of losses are carried forward.
} 
utilization of large NOLs typically results in a decrease in the valuation allowance and thus a lower GAAP ETR. ${ }^{14}$ In Section 3.1.1, we summarize our empirical validation of the link between NOLs and the valuation allowance conducted in the internet appendix.

Collectively, the above reasons suggest that the majority of firms that attain a low ETR are likely benefiting from large NOLs.

\section{Empirical analysis}

\subsection{Measurement of large NOLs}

The challenge in examining the impact of large NOLs on ETRs is finding a reliable measure of NOLs that is available for a large sample of firms. In particular, tax return data is not publicly available (nor available on a worldwide basis), and it is well known that Compustat NOL data is plagued with measurement error (Kinney and Swanson 1993; Mills et al. 2003; Heitzman and Lester 2020). Consequently, we use two alternative proxies to capture whether a firm has economically large NOLs. First, we use an intuitive proxy based on whether a firm reports an accumulated deficit on its balance sheet. Second, we identify firms that have large NOLs based on the predicted NOL benefit developed by Heitzman and Lester (2020). We describe each measure in turn.

\subsubsection{Accumulated deficit}

Retained earnings reported in the balance sheet provides a measure of the cumulative profitability of a firm over time (Altman 1968). A firm will report an accumulated deficit in retained earnings (i.e., negative retained earnings) when cumulative book losses exceed cumulative book profits. ${ }^{15}$ We argue that, when a firm reports an accumulated deficit, it is also likely to report economically large NOLs for tax purposes. Since book income and taxable income are not perfect substitutes and the carryback and carryforward procedures of net operating losses do not perfectly map into the calculation of retained earnings, we create an indicator variable (Deficit) that equals one if a firm's prior year retained earnings is negative and zero otherwise.

\footnotetext{
${ }^{14}$ As we discuss in detail in the internet appendix, when no valuation allowance is initially recognized, the GAAP tax benefit of NOLs is recognized in the year the loss occurs and thus NOLs do not affect the GAAP ETR in the future when they are utilized. However, when a valuation allowance initially offsets the NOL, the GAAP tax benefit of the NOL is deferred until the NOLs are utilized in future years. While we show there is a clear link between the use of NOLs and reversals of the valuation allowance, we acknowledge not all firms with large NOLs will record a valuation allowance.

${ }^{15}$ To demonstrate that losses are the primary driver of accumulated deficits, we regress the change in retained earnings on net income (with both variables scaled by beginning total assets) for a sample that includes both profit and loss firm-years. Theoretically, if net income were the only driver of changes in retained earnings, we would expect to see a coefficient of 1 for net income and an adjusted $\mathrm{R}^{2}$ of 1 . We find that the coefficient on net income is 0.964 ( $t$-statistic 191.46) with an adjusted $\mathrm{R}^{2}$ of $92.3 \%$ (untabulated). We find very similar results using a sample of only loss firm-years. While these findings provide evidence that losses are the primary driver of deficits, we acknowledge that a small number of deficits are likely attributed to other transactions (e.g., stock repurchases).
} 
The benefits of this proxy are that it is readily available and easy to compute for a large sample of firms with minimal sample attrition, it captures worldwide losses, and, most importantly, it should capture economically large NOLs that are likely to have the biggest impact on ETRs. Furthermore, since it is based on whether a firm has a cumulative book loss, it should capture NOLs that arise from real economic losses, rather than other forms of tax planning. That is, publicly traded firms generally prefer to engage in nonconforming tax avoidance, which reduces taxable income without reducing book income (Badertscher et al. 2009). Thus it seems unlikely that a large number of U.S. publicly traded firms would engage in such a high level of conforming tax avoidance that they reduce both book and taxable income to the extent it creates an accumulated deficit on their balance sheet.

The main limitation of this measure is that it is likely to miss relatively smaller NOLs or NOLs created by differences in the calculation of book and taxable income. However, by design, we are interested in identifying firms that suffered economically large losses and are now simply benefiting from the deduction for NOLs. Thus we are less concerned in our setting about the measure not capturing relatively smaller NOLs or NOLs created by book-tax differences.

To confirm that having an accumulated deficit is fairly common, we construct a typical tax avoidance sample with profitable firm-years from Compustat. ${ }^{16}$ Our sample begins in 1994 and ends in 2014. Consistent with prior literature, we exclude (1) firms incorporated outside of the United States, (2) firm-years with negative pretax income, (3) cash ETRs below zero or above one, and (4) regulated firms (SIC 6000-6999 and 4900-4949). We also exclude firms-years missing necessary data to calculate the following control variables: pretax return on assets (ROA); foreign income (Multinational); a subsidiary in a tax haven (Haven); leverage (Leverage); gross property, plant, and equipment $(P P E)$; research and development $(R \& D)$; stock option expense (Stock Option Expense); firm size (LnAssets); and market-to-book $(M T B)$. (See Appendix A for variable definitions.) ${ }^{17}$ This results in a sample of 46,816 firm-years. Table 1 reports descriptive statistics for this sample and illustrates that $25 \%$ of the observations have an accumulated deficit. This finding is consistent with the notion that a nontrivial number of the profit firms typically examined in the tax literature have economically large NOLs. Thus this benign tax position could play a major role in achieving a low ETR.

To validate this proxy (as well as confirm the level of measurement error inherent in Compustat NOL data), we use a random number generator to select 1,050 firm-years from our main sample (50 firms per year equally split between deficit and non-deficit firms) and hand-collect the deferred tax asset related to NOLs from the tax footnote in the $10-\mathrm{K}$ filing. This data is collected for year $t-1$, as that reflects the NOL from prior years that would be available for use during year $t$.

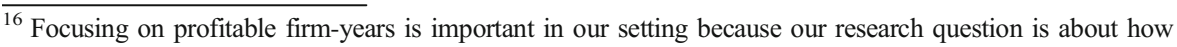
profitable firms attain low ETRs. Hence loss firm-years are not included in our primary sample.

${ }^{17}$ It is common in the literature to truncate or winsorize ETRs at 0 and 1 . We choose to truncate because ETRs less than 0 and greater than 1 are typically caused by atypical transactions that are not associated with actual tax positions, such as non-tax deductible goodwill recognized for financial accounting purposes or extreme reversals of the valuation allowance that are not tied to the use of NOLs (Schwab, Stomberg, and Xia 2020). However, all inferences are unchanged if we winsorize ETRs rather than truncating.
} 
As we explain in detail in the internet appendix, we conduct the following analyses. First, we compare the Compustat NOL data to our hand-collected NOL data. We find that Compustat fails to identify an NOL for roughly $42 \%$ of our sample that discloses a NOL in the tax footnote. Troublingly, we also find that Compustat misses a substantial number of firms that disclose large NOLs that are likely to have the biggest impact on ETRs.

Second, we compare the Deficit measure to our hand-collected NOL data. Consistent with our expectation that Deficit can identify firms that report large NOLs, we find that approximately $87 \%$ of deficit firms disclose NOLs. Further, we find that, among firms that report NOLs in their financial statements, the average deferred tax assets associated with NOLs for deficit firms are $25.1 \%$ of beginning total assets compared to only $3.4 \%$ for non-deficit firms. However, as expected, we also find that Deficit fails to identify relatively smaller NOLs.

Finally, we also use our hand-collected sample to confirm that NOLs can affect GAAP ETRs through changes in the valuation allowance. Specifically, the analysis reported in the internet appendix shows that $98 \%$ of deficit firms that attain a low GAAP ETR disclose a valuation allowance. More importantly, we find that for these firms the correlation between changes in the NOL deferred tax asset and changes in the valuation allowance is $0.75(p<0.01)$. This suggests there is a clear link between the use of NOLs and reversals of the valuation allowance. Furthermore, we find that the change in the valuation allowance is larger for deficit firms than for non-deficit firms.

Collectively, the validation tests described in the internet appendix suggest that Deficit is a valid proxy for economically large NOLs that are most likely to impact corporate taxpayer behavior and both cash and GAAP ETRs, with the caveat that Deficit will not capture relatively smaller NOLs.

\subsubsection{Predicted NOL benefit}

Our second proxy for large NOLs is based on the predicted NOL benefit calculated by Heitzman and Lester (2020). Heitzman and Lester (2020) use hand-collected NOL data from the tax footnote for a large sample of U.S. firms to construct a model that predicts the NOL benefit. Specifically, the authors regress their hand-collected NOL data from 2010 to 2015 on a number of readily available variables that reflect financial performance and other firm characteristics (including the presence of negative retained earnings) and then use the parameter estimates to construct predicted values for the NOL benefit.

Following their methodology, we use the parameter estimates from their determinants model (as described in detail in Appendix B) to construct Predicted NOL. Since we are interested in firms that report economically large NOLs that can significantly reduce ETRs, we then create an indicator variable (High Pred. NOL), which equals one if a firm's prior year Predicted NOL is in the top quartile and zero otherwise. Descriptive statistics for High Pred. NOL are presented in Table 1. Further, in untabulated analyses, we find that our proxies for large NOLs (Deficit and High Pred. NOL) have a Pearson correlation of 0.74 , suggesting these proxies capture a similar economic construct. 
Table 1 Descriptive Statistics

\begin{tabular}{lllllll}
\hline Variables & $\mathrm{N}$ & Mean & Std. Dev. & $25 \%$ & Median & $75 \%$ \\
\hline Deficit & 46,816 & 0.250 & 0.433 & 0.000 & 0.000 & 1.000 \\
High Pred. NOL & 46,816 & 0.250 & 0.433 & 0.000 & 0.000 & 1.000 \\
Cash ETR 1yr & 46,816 & 0.253 & 0.181 & 0.101 & 0.250 & 0.361 \\
ROA & 46,816 & 0.135 & 0.115 & 0.059 & 0.106 & 0.176 \\
Multinational & 46,816 & 0.403 & 0.490 & 0.000 & 0.000 & 1.000 \\
Haven & 46,816 & 0.328 & 0.469 & 0.000 & 0.000 & 1.000 \\
Leverage & 46,816 & 0.246 & 0.264 & 0.024 & 0.189 & 0.364 \\
PPE & 46,816 & 0.309 & 0.270 & 0.107 & 0.229 & 0.429 \\
R\&D & 46,816 & 0.030 & 0.057 & 0.000 & 0.000 & 0.031 \\
Stock Options & 46,816 & 0.008 & 0.016 & 0.000 & 0.003 & 0.009 \\
LnAssets & 46,816 & 5.827 & 2.067 & 4.389 & 5.796 & 7.228 \\
MTB & 46,816 & 2.919 & 3.475 & 1.304 & 2.136 & 3.550 \\
\hline
\end{tabular}

Cash ETR 1yr is the firm's continuous cash ETR, calculated as cash taxes paid (TXPD) divided by pretax income (PI). For this variable, we require firm-years to have positive pretax income and an ETR between $[0,1]$. See Appendix A for all other variable definitions

\subsection{Univariate analysis}

We begin our empirical analysis with a set of univariate tests that examine the extent to which firms with large NOLs attain low ETRs. To do so, we create an indicator variable that equals one if a firm has an ETR between 0 and $10 \%$ and zero otherwise. ${ }^{18}$ We create separate indicators for annual cash and GAAP ETRs (Low Cash ETR 1yr and Low GAAP ETR $1 y r$ ) and for common long-run cash ETRs examined in the academic literature (Low Cash ETR 3yr and Low Cash ETR 5yr). We calculate the low annual ETRs for year $t$ and the low three- (five-) year ETRs using data for $t$ to $t+2(t+4)$. (See Appendix A for variable definitions.) As the results of our tests are similar for both large NOL proxies, for the sake of brevity, we only discuss the findings for the Deficit measure. However, note that finding similar results with both measures provides additional comfort that we are capturing large NOLs.

In our first univariate test, we compare the probability that firms with large NOLs (Deficit $=1$ ) attain a low ETR, relative to firms without large NOLs (Deficit $=0)$. These results are reported in Table 2 Panel A. Consistent with our expectation, we find that firms with large NOLs have a significantly higher probability of attaining a low ETR. For example, the probability that a large NOL firm attains an annual cash (GAAP) ETR between 0 and $10 \%$ is approximately $56 \%$ (34\%), compared to only $14 \%$ (3\%) for firms without large NOLs. Thus firms with large NOLs are roughly four (12) times more likely to attain a low ETR. Similarly, we find that the probability that a firm with large NOLs attains a low three(five-) year cash ETR is approximately $40 \%$ (31\%), relative to only $9 \%$ (7\%) for firms without large NOLs. The differences between each of these probabilities for firms with and without large NOLs are statistically significant $(p<0.01)$.

\footnotetext{
$\overline{18}$ To put this in perspective, during our entire sample period, the statutory rate was $35 \%$.
} 


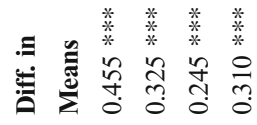

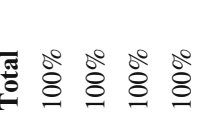

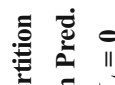

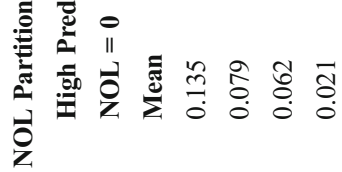

?ํํㄹ

窇

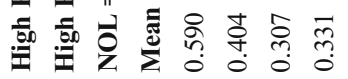

密 ॥

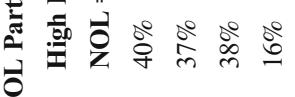

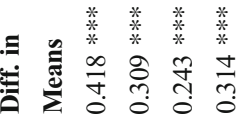

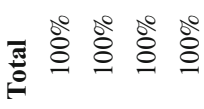

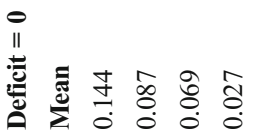

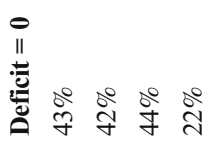

בี้

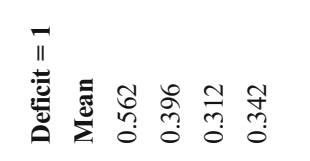

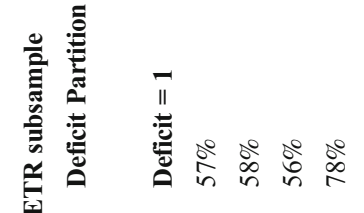

$\stackrel{\circ}{\varrho}$

告

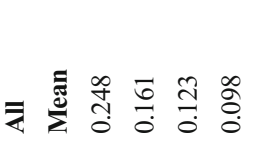

量

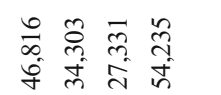

를

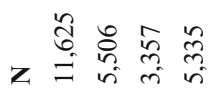

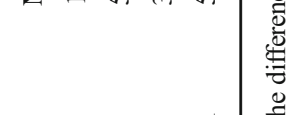

इे के

运运通

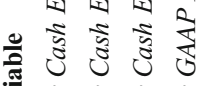

II)

$\Rightarrow \overrightarrow{~ क े ~ ह ै ~}$

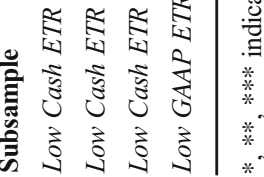


In our second univariate test, we examine the subset of firms that have low ETRs (e.g., Low Cash ETR = 1) and simply count the number of low ETR firms with and without large NOLs. The results are reported in Table 2 Panel B. While large NOL firms only make up $25 \%$ of our overall sample, we find that $57 \%(78 \%)$ of the subset of firms that have a low annual cash (GAAP) ETR are in fact large NOL firms. We also find that, among firms that have a low three- (five-) year cash ETR, 58\% (56\%) are large NOL firms. Thus, across all of these different ETR measures, large NOL firms constitute the majority of firms with low ETRs.

To put these results into perspective, we also perform the same univariate tests using proxies for firms with more opportunities to engage in aggressive tax planning. Specifically, we compare the probability of attaining a low ETR for firms with and without foreign income (i.e., multinational versus domestic firms) and for firms with and without a subsidiary in a tax haven. Both of these proxies capture income shifting opportunities that have been a prominent subject of concern by policymakers.

In Table 3 Panel A, we find that firms with foreign income (Multinational $=1$ ) have a significantly lower probability of having a low ETR than firms without foreign income (i.e., domestic firms). For example, the probability that a multinational firm will have a low annual cash (GAAP) ETR is approximately $18 \%(6 \%)$, compared to $29 \%$ (12\%) for domestic firms. Similarly, we find that the probability that a multinational firm will have a low three- (five-) year cash ETR is approximately $11 \%(9 \%)$, relative to $20 \%$ (15\%) for domestic firms. Again, the differences between each of these probabilities for multinational and domestic firms are statistically significant $(p<$ $0.01)$.

Next, in Table 3 Panel B, we examine the subset of firms that have low ETRs (e.g., Low Cash ETR = 1) and simply count how many of them are multinational and domestic firms. While multinational firms make up $40 \%$ of our overall sample, we find that only $29 \%(21 \%)$ of the subset of firms that have a low annual cash (GAAP) ETR are in fact multinational firms. Thus firms with foreign income (i.e., international transfer pricing opportunities), which are often assumed to have more opportunities for aggressive tax planning, are the minority of firms with low annual ETRs.

Table 3 also reports similar results for firms with a subsidiary in a tax haven. For example, in Table 3 Panel A, we find that firms with a subsidiary in a tax haven (Haven $=1$ ) have a significantly lower probability of attaining a low ETR. Similarly, we see that, while haven firms make up $33 \%$ of our overall sample, when we examine the subset of firms that have low cash (GAAP) ETRs, only $23 \%(16 \%)$ are haven firms (Table 3 Panel B). Thus haven firms are also the minority of firms with low annual ETRs. ${ }^{19}$

Overall, these univariate tests suggest that large NOLs are a primary way that firms attain low ETRs, which is consistent with our prediction.

\footnotetext{
${ }^{19}$ Large NOLs appear to play some role in why domestic firms are more likely than multinational firms to attain low ETRs. For example, in untabulated analyses, we find 47\% (63\%) of multinational firms with low cash (GAAP) ETRs have large NOLs, whereas $61 \%(83 \%)$ of domestic firms with low cash (GAAP) ETRs have large NOLs. Similarly, 42\% (56\%) of haven firms with low cash (GAAP) ETRs have large NOLs, whereas $61 \%(83 \%)$ of non-haven firms with low cash (GAAP) ETRs have large NOLs.
} 


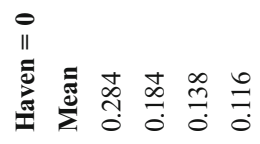

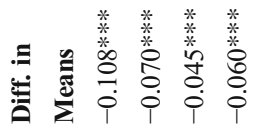

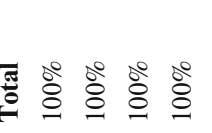

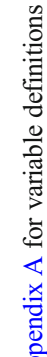

竞

"I

$\begin{array}{llll}0 & 0 & 0 \\ 5 & 0 & 0 \\ 0 & 0 & 0 & 0\end{array}$

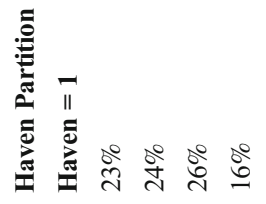

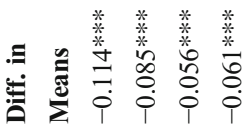

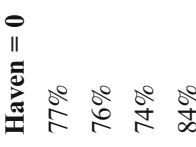

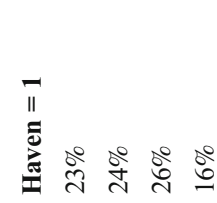

这

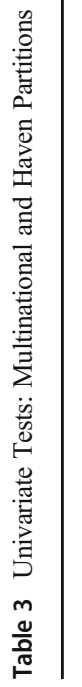

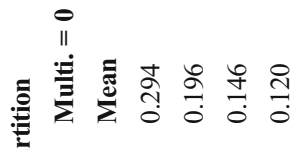

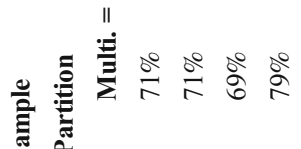

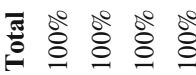

药

을

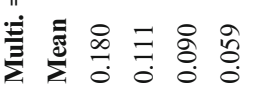

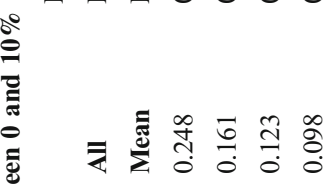

.

离

त

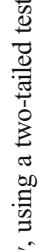

. 
Table 4 Multivariate Analysis: Low ETRs (from 0 to 10\%)

\begin{tabular}{|c|c|c|c|c|c|}
\hline \multirow[t]{2}{*}{ Dependent Variable: } & \multirow[t]{2}{*}{ Pr. Sign } & \multicolumn{2}{|c|}{ Low Cash ETR 1yr } & \multicolumn{2}{|c|}{ Low GAAP ETR $1 y r$} \\
\hline & & (1) & (2) & (3) & (4) \\
\hline Deficit & $(+)$ & $\begin{array}{l}0.336 * * * \\
(43.72)\end{array}$ & & $\begin{array}{l}0.240 * * * \\
(39.01)\end{array}$ & \\
\hline High Pred. NOL & $(+)$ & & $\begin{array}{l}0.378 * * * \\
(51.84)\end{array}$ & & $\begin{array}{l}0.237 * * * \\
(42.73)\end{array}$ \\
\hline$R O A$ & & $\begin{array}{l}-0.219 * * * \\
(-9.60)\end{array}$ & $\begin{array}{l}-0.179 * * * \\
(-8.31)\end{array}$ & $\begin{array}{l}-0.038 * * \\
(-2.14)\end{array}$ & $\begin{array}{l}-0.018 \\
(-1.01)\end{array}$ \\
\hline Multinational & & $\begin{array}{l}-0.053 * * * \\
(-7.90)\end{array}$ & $\begin{array}{l}-0.058 * * * \\
(-8.97)\end{array}$ & $\begin{array}{l}-0.020 * * * \\
(-4.69)\end{array}$ & $\begin{array}{l}-0.021 * * * \\
(-5.05)\end{array}$ \\
\hline Haven & & $\begin{array}{l}-0.009 \\
(-1.47)\end{array}$ & $\begin{array}{l}-0.017 \text { *** } \\
(-2.80)\end{array}$ & $\begin{array}{l}0.019 * * * \\
(4.94)\end{array}$ & $\begin{array}{l}0.016^{* * *} \\
(4.13)\end{array}$ \\
\hline Leverage & & $\begin{array}{l}0.069 * * * \\
(6.28)\end{array}$ & $\begin{array}{l}0.093 * * * \\
(9.05)\end{array}$ & $\begin{array}{l}0.067 * * * \\
(8.24)\end{array}$ & $\begin{array}{l}0.087 * * * \\
(11.20)\end{array}$ \\
\hline$P P E$ & & $\begin{array}{l}0.125^{* * * *} \\
(7.82)\end{array}$ & $\begin{array}{l}0.100^{* * * *} \\
(6.51)\end{array}$ & $\begin{array}{l}-0.008 \\
(0.87)\end{array}$ & $\begin{array}{l}-0.025^{* * *} \\
(-2.70)\end{array}$ \\
\hline$R \& D$ & & $\begin{array}{l}0.531 * * * \\
(8.27)\end{array}$ & $\begin{array}{l}0.437 * * * \\
(6.99)\end{array}$ & $\begin{array}{l}0.408^{* * * *} \\
(7.94)\end{array}$ & $\begin{array}{l}0.351 * * * \\
(6.71)\end{array}$ \\
\hline Stock Options & & $\begin{array}{l}1.815^{* * *} \\
(9.62)\end{array}$ & $\begin{array}{l}1.757 * * * \\
(9.60)\end{array}$ & $\begin{array}{l}1.039^{* * * *} \\
(6.48)\end{array}$ & $\begin{array}{l}1.082 * * * \\
(6.62)\end{array}$ \\
\hline LnAssets & & $\begin{array}{l}-0.030 * * * \\
(-16.00)\end{array}$ & $\begin{array}{l}-0.023 * * * \\
(-12.81)\end{array}$ & $\begin{array}{l}-0.033 * * * \\
(-24.11)\end{array}$ & $\begin{array}{l}-0.031 * * * \\
(-23.23)\end{array}$ \\
\hline$M T B$ & & $\begin{array}{l}-0.001 \\
(-0.72)\end{array}$ & $\begin{array}{l}-0.002^{* * *} \\
(-2.76)\end{array}$ & $\begin{array}{l}-0.002 * * * \\
(-2.92)\end{array}$ & $\begin{array}{l}-0.003 * * * \\
(-4.46)\end{array}$ \\
\hline Intercept & & $\begin{array}{l}0.342 * * * \\
(15.29)\end{array}$ & $\begin{array}{l}0.290 * * * \\
(13.85)\end{array}$ & $\begin{array}{l}0.241 * * * \\
(20.26)\end{array}$ & $\begin{array}{l}0.219 * * * \\
(19.11)\end{array}$ \\
\hline Industry \& Year F.E. & & Yes & Yes & Yes & Yes \\
\hline Adj. $\mathrm{R}^{2}$ & & 0.239 & 0.263 & 0.250 & 0.254 \\
\hline $\mathrm{N}$ & & 46,816 & 46,816 & 54,235 & 54,235 \\
\hline
\end{tabular}

$*, * *, * * *$ indicate that the estimated coefficient is statistically significant at the $10 \%, 5 \%$, and $1 \%$ levels, respectively, using a two-tailed test. Coefficient estimates are reported with corresponding $t$-statistics in parentheses, where standard errors are clustered by firm. See Appendix A for variable definitions

\subsection{Multivariate analysis}

We next examine whether firms with large NOLs are more likely to have low ETRs using multivariate regressions. This allows us to control for other tax positions that may lead firms to have low ETRs. To perform these analyses, we employ the following regression model.

$$
\text { Low ETR }_{\mathrm{it}}=\beta_{0}+\beta_{1} \text { Large NOL }_{\mathrm{it}}+\sum_{\mathrm{k}} \beta_{\mathrm{k}} \text { Controls }_{\mathrm{it}}+\varepsilon_{\mathrm{it}} \text {, }
$$

where, as previously discussed, Low ETR is an indicator variable that equals one if a 
firm has an ETR between 0 and $10 \%$ and zero otherwise. We calculate Low ETR separately for the annual cash ETR (Low Cash ETR 1yr) and annual GAAP ETR (Low GAAP ETR 1yr). Large NOL represents our independent variable of interest, Deficit or High Pred. NOL, and Controls include the variables previously noted in our sample requirements. The model also includes year and industry fixed effects (Fama French 48), with standard errors clustered by firm, and all continuous variables are winsorized at the top and bottom $1 \%$ to mitigate the influence of outliers. We perform this analysis using a linear probability model (i.e., OLS) for ease of interpreting economic magnitudes and including fixed effects (Hanlon and Hoopes 2014; Christensen 2016). ${ }^{20} \mathrm{We}$ predict that firms with large NOLs will be more likely to have low ETRs $\left(\beta_{1}>0\right)$.

Table 4 reports the results of these analyses. Again, as the results from our two large NOL proxies are similar, for the sake of brevity, we focus our discussion on the Deficit measure. Consistent with our expectation, Table 4 shows that large NOL firms have a significantly higher probability of attaining a low annual cash and GAAP ETR, relative to firms without large NOLs ( $t$-statistics of 43.72 and 39.01 , respectively). The magnitudes of these effects are also economically significant. Holding all else constant, the probability that large NOL firms will have a low annual cash (GAAP) ETR is $50.0 \%(28.4 \%)$, relative to only $16.4 \%(4.4 \%)$ for firms without large NOLs. Thus the probability that a large NOL firm will have a low cash (GAAP) ETR is $33.6 \%(24.0 \%)$ percentage points higher or roughly three (six) times more likely than firms without large NOLs. ${ }^{21}$ We also find similar results for low long-run ETRs. (See the internet appendix for details.)

To put these findings into perspective, when we examine the coefficients on measures that capture income shifting opportunities (Multinational and Haven), we see that, in the majority of cases, the estimated coefficients are negative and statistically significant. Thus firms with foreign income or a subsidiary in a tax haven tend to be less likely to have a low ETR. These findings again suggest that aggressive income shifting is not the primary way the average low ETR firm avoids paying taxes.

Collectively, these multivariate findings provide further evidence that large NOLs appear to be the more common way of attaining low ETRs. These findings are consistent with the idea that the potential costs of aggressive tax planning constrain firms from achieving low ETRs and expand our understanding of specifically how so many firms attain low ETRs.

\subsection{Distribution of large NOL firms across ETRs}

Our previous analyses suggest that large NOLs are a primary way that firms attain low ETRs. To provide further evidence that the findings are indeed attributable to large NOLs, we next examine how firms with large NOLs are dispersed across the ETR distribution (0 to 100\%). If large NOLs help firms attain low ETRs, we expect that large NOL firms are more likely to be concentrated in lower portions of the ETR distribution than higher portions. To assess this, we divide the firms in our sample into

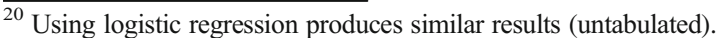

${ }^{21}$ Since Deficit is a binary explanatory variable, its coefficient of $0.336(0.240)$ in Table 4 is just the difference in the probability that Low Cash ETR 1yr (Low GAAP ETR 1yr $)=1$ when Deficit $=1$ of 50.0 (28.4), compared to 16.4 (4.4) when Deficit $=0$, holding all other explanatory variables fixed.
} 


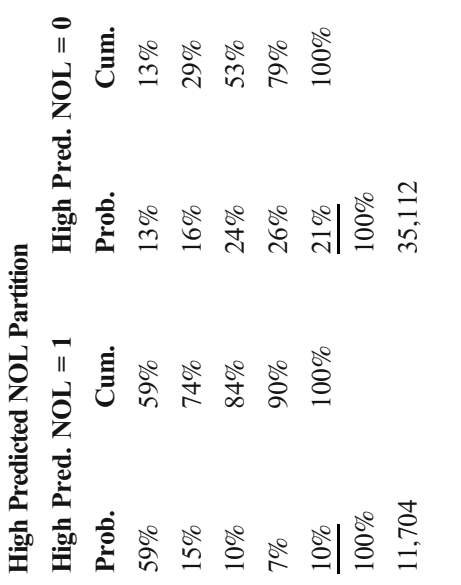

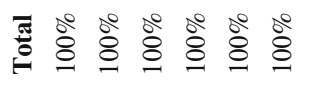

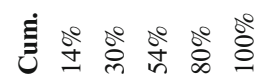

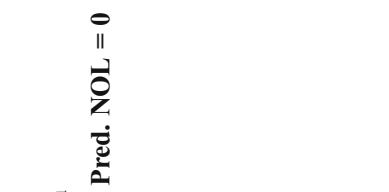

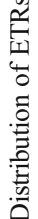

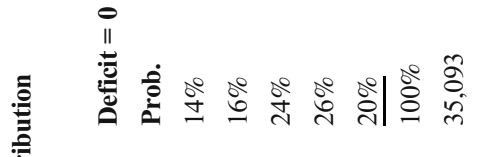

:

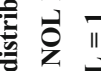

总

§

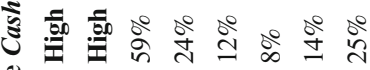

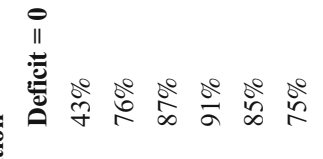

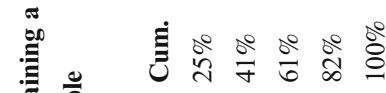




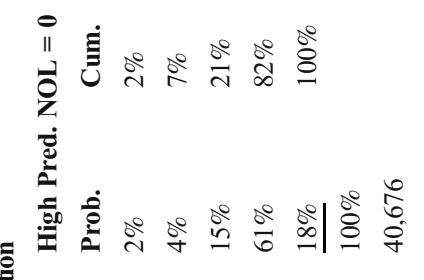

西

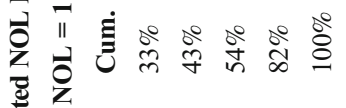

:

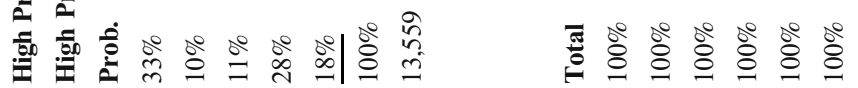

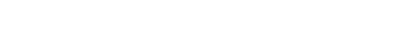

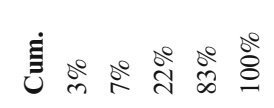

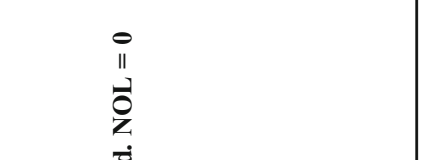

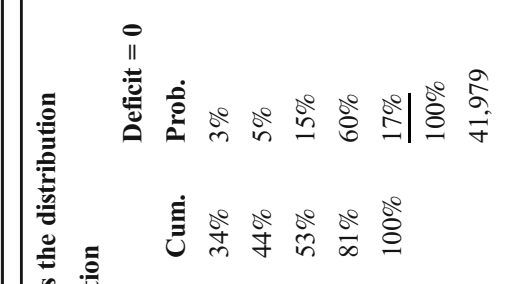

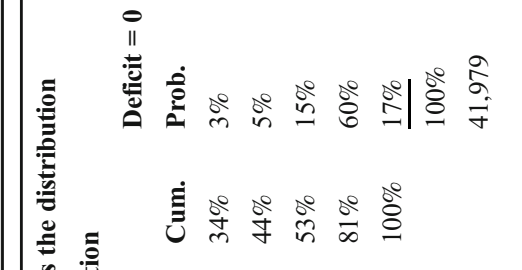

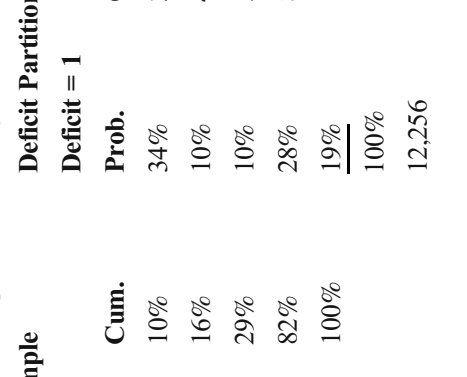

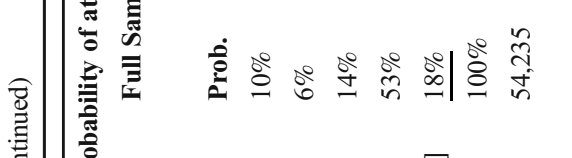

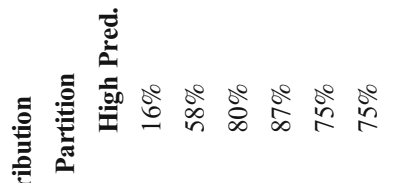

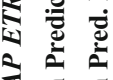

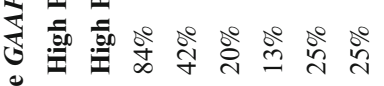

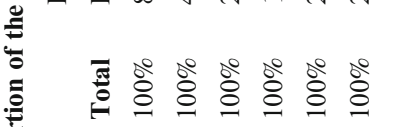

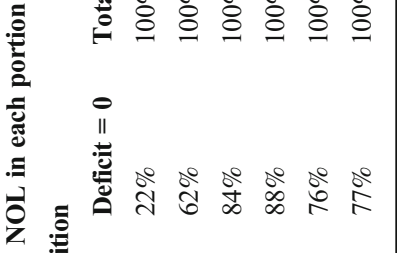

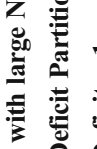

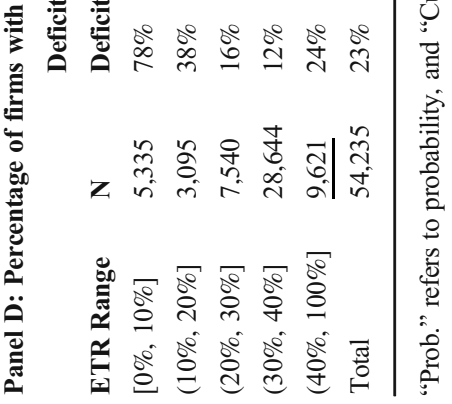




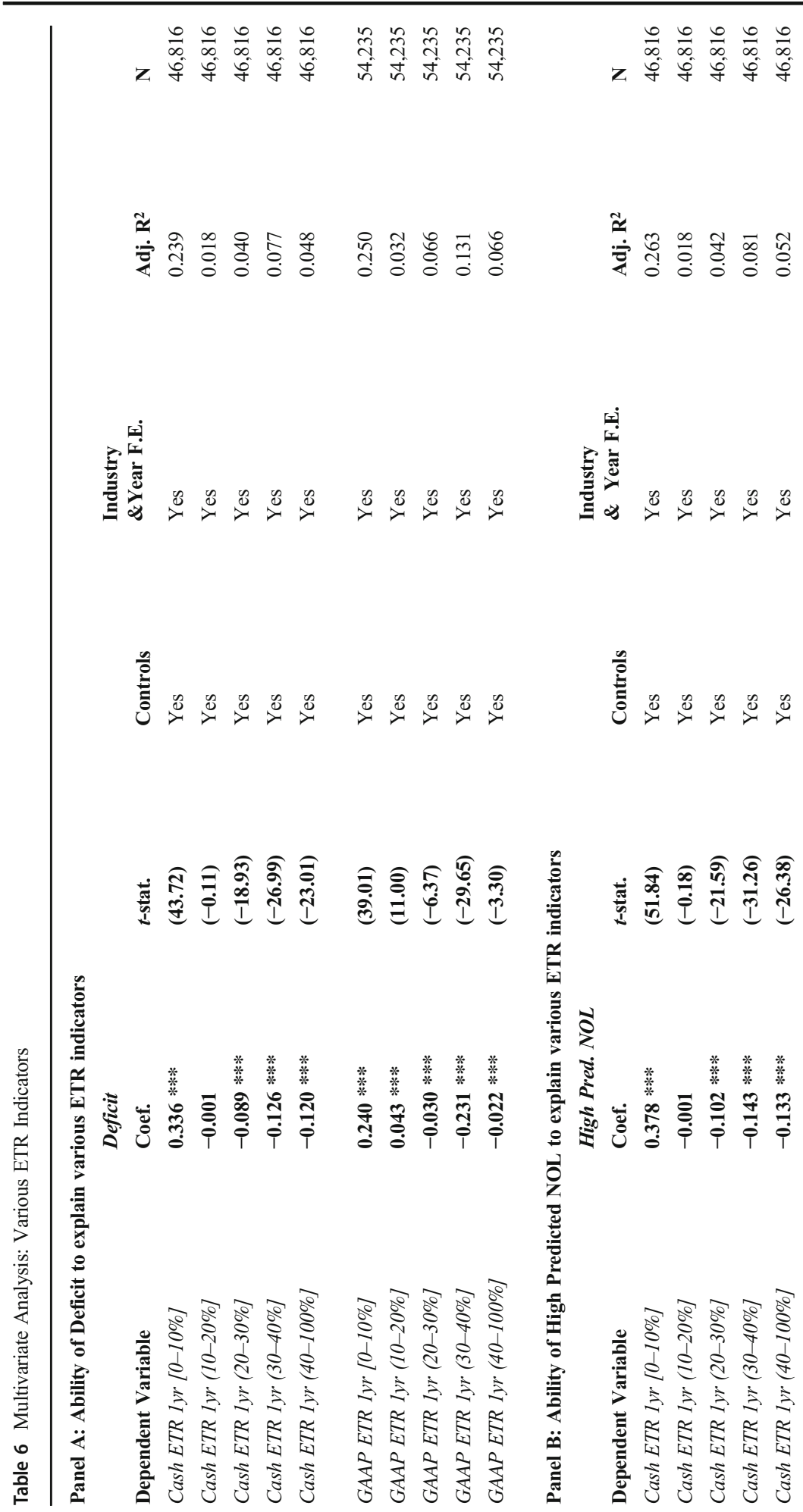




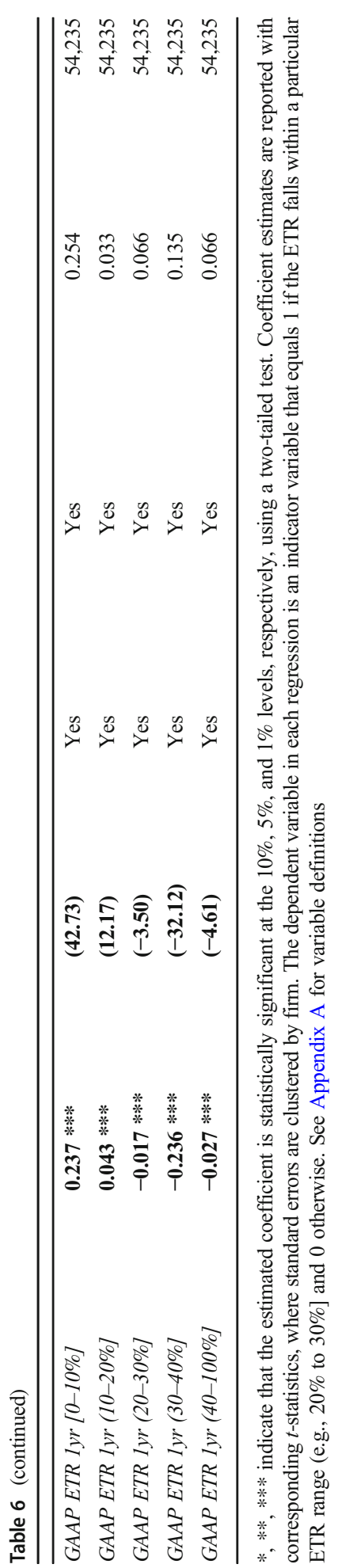

\section{昞 Springer}




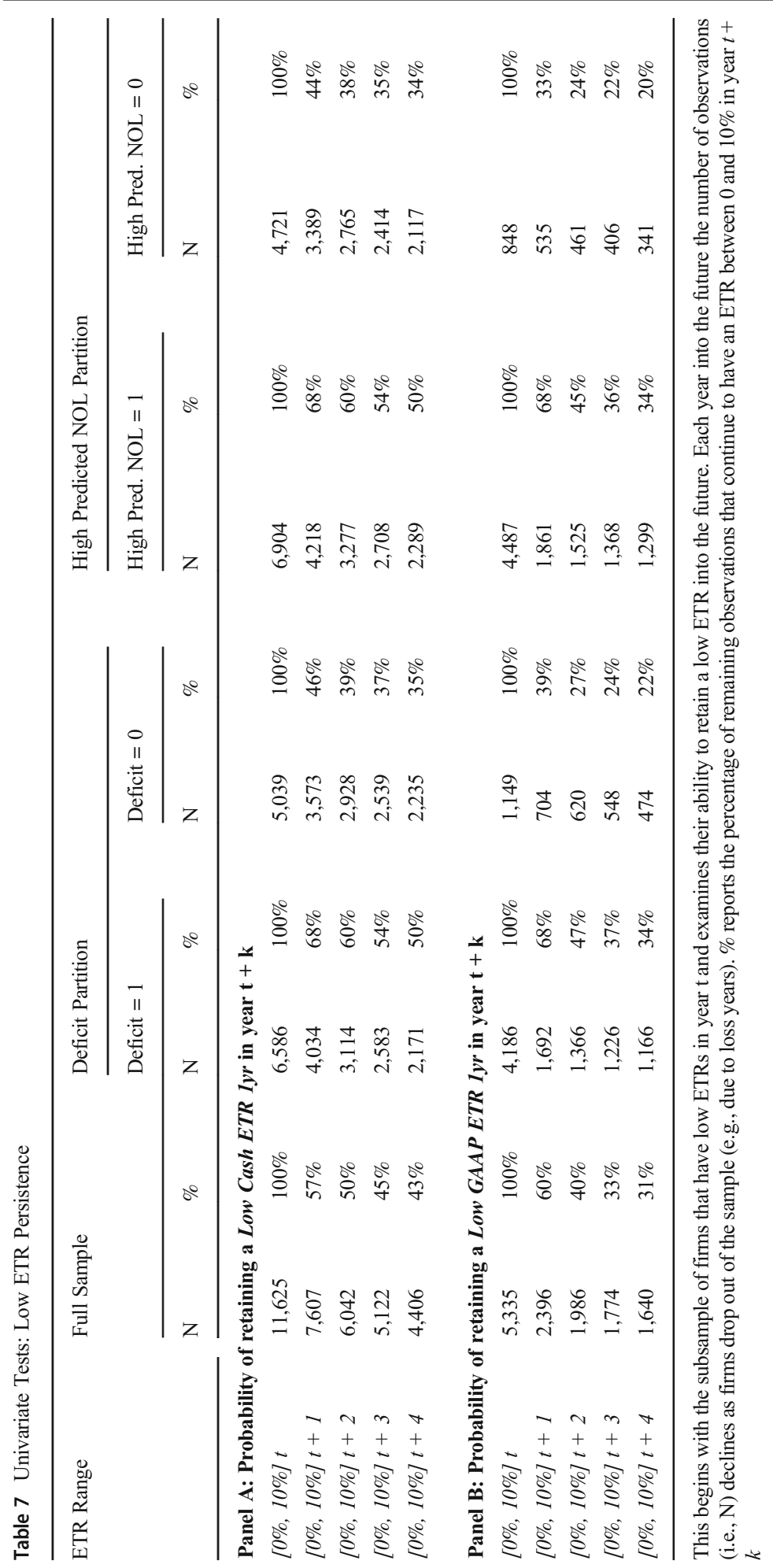


five groups based on their ETR: (1) 0 to $10 \%$, (2) $10 \%$ to $20 \%$, (3) $20 \%$ to $30 \%$, (4) $30 \%$ to $40 \%$, and (5) greater than $40 \%$. Table 5 reports univariate results for the probability of attaining an ETR in each group, and the percentage of firms with large NOLs in each group, for both Cash ETR 1yr (Panels A and B) and GAAP ETR 1yr (Panels C and D).

Consistent with our expectation, Panels $\mathrm{A}$ and $\mathrm{C}$ illustrate that firms with large NOLs are concentrated in lower ETR groups and have a low probability of being in higher ETR groups. ${ }^{22}$ Moreover, Panels B and D suggest that firms with large NOLs make up the majority of the sample in the low ETR group (0 to 10\%), and the reverse is true in all other ETR groups. In untabulated analysis, we also examine the ETR distributions of firms with opportunities to engage in aggressive tax planning (Multinational and Haven). While we showed in Table 3 that multinational and haven firms have a lower probability of having an ETR between 0 and $10 \%$ and are underrepresented in the 0 to $10 \%$ group, we find these firms have a higher probability of having an ETR in the $10 \%$ to $20 \%$ and $20 \%$ to $30 \%$ groups and are overrepresented in the $10 \%$ to $20 \%$ and $20 \%$ to $30 \%$ groups.

We also estimate multivariate regressions to examine the likelihood that firms with large NOLs attain ETRs within each of the five groups. These regressions follow Eq. (1), except the dependent variable becomes an indicator for whether the firm had an ETR within a particular ETR group (e.g., 20\% to 30\%). Table 6 reports the results of these regressions. As expected, the findings generally mirror the univariate results. Firms with large NOLs are more likely to be in the 0 to $10 \%$ group and less likely to be in the $20 \%$ to $30 \%, 30 \%$ to $40 \%$, and $40 \%$ to $100 \%$ groups. We also find that multinational and haven firms are generally less likely to be in the 0 to $10 \%$ and $30 \%$ to $40 \%$ groups and more likely to be in the $10 \%$ to $20 \%$ and $20 \%$ to $30 \%$ groups (not tabulated). Overall, the results in Tables 5 and 6 help validate that large NOLs are a primary way that firms attain low ETRs by showing that firms with large NOLs are more likely to be concentrated in lower ETR groups.

\section{Do low ETR firms incur tax risk?}

The results in Section 3 provide evidence that the majority of firms with low ETRs are primarily benefiting from large NOLs rather than aggressive tax planning. Since there is a conceptual link between tax aggressiveness and tax risk (Blouin 2014), this finding has implications for the relation between low ETRs and tax risk. There is currently conflicting evidence regarding whether low ETR firms incur tax risk. On one hand, Dyreng et al. (2019) find that firms with lower cash ETRs recognize larger additions in UTBs, suggesting that as firms avoid more taxes, they incur more tax risk. On the other hand, Guenther et al. (2017) find that ETRs are not negatively associated with future tax rate volatility, suggesting that lower ETRs are likely driven by benign tax positions.

\footnotetext{
${ }^{22}$ Interestingly, the probability of firms without large NOLs obtaining GAAP ETR $1 y \mathrm{r}$ between $30 \%$ and $40 \%$ is $60 \%$, suggesting that most firms without large NOLs have one-year GAAP ETRs around the statutory rate. We also find that the probability of having GAAP ETR $1 y r$ above $40 \%$ is similar for firms with and without large NOLs. This is consistent with the findings of Schwab et al. (2020) that items, such as non-deductible goodwill impairments, can distort high ETRs.
} 


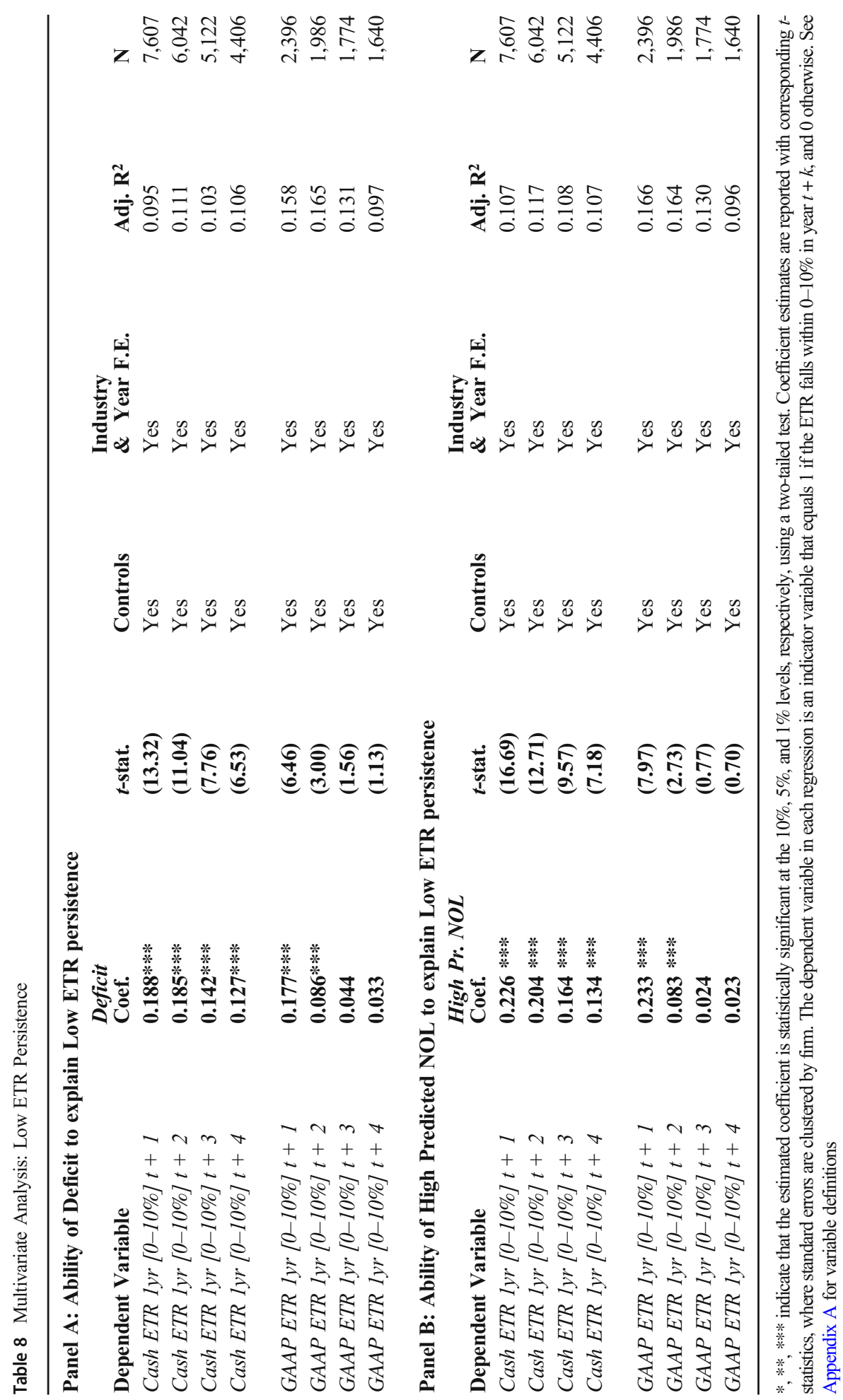


Our finding that the majority of low ETR firms are primarily benefiting from large NOLs (i.e., a benign tax position) suggests that, on average, low ETR firms do not incur significant tax risk. To investigate this prediction, we conduct three sets of tests. We first examine whether large NOLs allow firms to persistently retain a low ETR. We then examine the relation between low ETRs and both additions to UTBs (Dyreng et al. 2019) and future tax rate volatility (Guenther et al. 2017).

\subsection{Persistence of low ETRs for firms with large NOLs}

To understand the relation between low ETRs and tax risk, we first examine whether large NOLs allow firms to persistently retain a low ETR. Although simply having an NOL is unlikely to result in persistently low ETRs, if firms have amassed large NOLs, they should be able to retain a low ETR for several years into the future. In contrast, firms without large NOLs would likely need to engage in aggressive tax planning to obtain a low ETR, which

Table 9 Low ETRs and Ex Ante Tax Risk

\begin{tabular}{|c|c|c|c|c|c|c|}
\hline \multirow{3}{*}{$\begin{array}{l}\text { Dependent Variable: } \\
\text { ETR Distribution: }\end{array}$} & \multicolumn{6}{|c|}{ UTB Additions } \\
\hline & \multicolumn{3}{|l|}{ Cash ETR } & \multicolumn{3}{|c|}{ GAAP ETR } \\
\hline & (1) & (2) & (3) & (4) & (5) & (6) \\
\hline $\operatorname{ETR}[0-10 \%]$ & $\begin{array}{l}0.004 \\
(0.34)\end{array}$ & $\begin{array}{l}0.046^{* * *} \\
(2.72)\end{array}$ & $\begin{array}{l}0.060 \text { *** } \\
(3.17)\end{array}$ & $\begin{array}{l}0.021 \\
(1.12)\end{array}$ & $\begin{array}{l}0.126 * * * \\
(3.41)\end{array}$ & $\begin{array}{l}0.140^{* * *} \\
(3.04)\end{array}$ \\
\hline ETR $(10-20 \%]$ & $\begin{array}{l}0.036 * * * \\
(3.12)\end{array}$ & $\begin{array}{l}0.038^{* * * *} \\
(3.21)\end{array}$ & $\begin{array}{l}0.040^{* * * *} \\
(3.31)\end{array}$ & $\begin{array}{l}0.124 * * * \\
(7.09)\end{array}$ & $\begin{array}{l}0.127 * * * \\
(7.20)\end{array}$ & $\begin{array}{l}0.130^{* * * *} \\
(7.28)\end{array}$ \\
\hline ETR $(20-30 \%]$ & $\begin{array}{l}0.012 \\
(1.41)\end{array}$ & $\begin{array}{l}0.012 \\
(1.42)\end{array}$ & $\begin{array}{l}0.013 \\
(1.47)\end{array}$ & $\begin{array}{l}0.072 * * * \\
(6.49)\end{array}$ & $\begin{array}{l}0.071 * * * \\
(6.49)\end{array}$ & $\begin{array}{l}0.073 * * * \\
(6.57)\end{array}$ \\
\hline ETR $(40-100 \%]$ & $\begin{array}{l}-0.017 * \\
(-1.95)\end{array}$ & $\begin{array}{l}-0.016^{*} \\
(-1.83)\end{array}$ & $\begin{array}{l}-0.015^{*} \\
(-1.66)\end{array}$ & $\begin{array}{l}0.014 \\
(1.25)\end{array}$ & $\begin{array}{l}0.017 \\
(1.61)\end{array}$ & $\begin{array}{l}0.021^{* *} \\
(1.99)\end{array}$ \\
\hline Deficit & & $\begin{array}{l}-0.016 \\
(-1.15)\end{array}$ & & & $\begin{array}{l}-0.024 * \\
(-1.76)\end{array}$ & \\
\hline Deficit $\times$ ETR $[0-10 \%]$ & & $\begin{array}{l}-0.071 * * * \\
(-3.16)\end{array}$ & & & $\begin{array}{l}-0.152 * * * \\
(-3.67)\end{array}$ & \\
\hline High Pr. NOL & & & $\begin{array}{l}-0.028^{* *} \\
(-2.11)\end{array}$ & & & $\begin{array}{l}-0.040 \text { *** } \\
(-3.45)\end{array}$ \\
\hline High Pr. NOL $\times$ ETR $[0-10 \%]$ & & & $\begin{array}{l}-0.078 * * * \\
(-3.34)\end{array}$ & & & $\begin{array}{l}-0.137 * * * \\
(-2.77)\end{array}$ \\
\hline Intercept & $\begin{array}{l}0.090 * * * \\
(3.84)\end{array}$ & $\begin{array}{l}0.091 * * * \\
(4.02)\end{array}$ & $\begin{array}{l}0.098 * * * \\
(4.29)\end{array}$ & $\begin{array}{l}0.049 * * \\
(2.34)\end{array}$ & $\begin{array}{l}0.055^{* * * *} \\
(2.76)\end{array}$ & $\begin{array}{l}0.060 \text { *** } \\
(2.92)\end{array}$ \\
\hline Industry \& Year FE & Yes & Yes & Yes & Yes & Yes & Yes \\
\hline Adj. $R^{2}$ & 0.090 & 0.094 & 0.096 & 0.106 & 0.112 & 0.113 \\
\hline $\mathrm{N}$ & 10,319 & 10,319 & 10,319 & 10,357 & 10,357 & 10,357 \\
\hline
\end{tabular}

$*, * *, * * *$ indicate that the estimated coefficient is statistically significant at the $10 \%, 5 \%$, and $1 \%$ levels, respectively, using a two-tailed test. Coefficient estimates are reported with corresponding $t$-statistics, where standard errors are clustered by firm. See Appendix A for variable definitions 
Table 10 Low ETRs and Ex Post Tax Risk

\begin{tabular}{|c|c|c|c|c|c|c|}
\hline \multirow{3}{*}{$\begin{array}{l}\text { Dependent Variable: } \\
\text { ETR Distribution: }\end{array}$} & \multicolumn{6}{|c|}{ Future Cash ETR Volatility } \\
\hline & \multicolumn{3}{|l|}{ Cash ETR } & \multicolumn{3}{|l|}{ GAAP ETR } \\
\hline & (1) & (2) & (3) & (4) & (5) & (6) \\
\hline $\operatorname{ETR}[0-10 \%]$ & $\begin{array}{l}-0.001 \\
(-0.22)\end{array}$ & $\begin{array}{l}0.006^{*} \\
(1.93)\end{array}$ & $\begin{array}{l}0.006^{* *} \\
(1.98)\end{array}$ & $\begin{array}{l}-0.020 * * * \\
(-6.90)\end{array}$ & $\begin{array}{l}-0.005 \\
(-1.03)\end{array}$ & $\begin{array}{l}-0.005 \\
(-0.73)\end{array}$ \\
\hline ETR $(10-20 \%]$ & $\begin{array}{l}0.009 * * * \\
(4.06)\end{array}$ & $\begin{array}{l}0.007 * * * \\
(3.47)\end{array}$ & $\begin{array}{l}0.007 * * * \\
(3.11)\end{array}$ & $\begin{array}{l}0.005 \\
(1.46)\end{array}$ & $\begin{array}{l}0.003 \\
(0.94)\end{array}$ & $\begin{array}{l}0.002 \\
(0.66)\end{array}$ \\
\hline ETR $(20-30 \%]$ & $\begin{array}{l}0.004^{* *} \\
(2.12)\end{array}$ & $\begin{array}{l}0.003^{*} \\
(1.94)\end{array}$ & $\begin{array}{l}0.003^{*} \\
(1.83)\end{array}$ & $\begin{array}{l}-0.003 \\
(-1.58)\end{array}$ & $\begin{array}{l}-0.004^{*} \\
(-1.66)\end{array}$ & $\begin{array}{l}-0.004 * \\
(-1.84)\end{array}$ \\
\hline ETR $(40-100 \%]$ & $\begin{array}{l}0.021^{* * * *} \\
(11.09)\end{array}$ & $\begin{array}{l}0.020 * * * \\
(10.85)\end{array}$ & $\begin{array}{l}0.020 * * * \\
(10.78)\end{array}$ & $\begin{array}{l}0.017 * * * \\
(8.55)\end{array}$ & $\begin{array}{l}0.017 * * * \\
(8.20)\end{array}$ & $\begin{array}{l}0.017 * * * \\
(8.14)\end{array}$ \\
\hline Deficit & & $\begin{array}{l}0.011^{* * * *} \\
(4.08)\end{array}$ & & & $\begin{array}{l}0.007 * * * \\
(3.05)\end{array}$ & \\
\hline Deficit $\times$ ETR $[0-10 \%]$ & & $\begin{array}{l}-0.021 * * * \\
(-5.22)\end{array}$ & & & $\begin{array}{l}-0.026 * * * \\
(-4.26)\end{array}$ & \\
\hline High Pr. NOL & & & $\begin{array}{l}0.013^{* * *} \\
(5.66)\end{array}$ & & & $\begin{array}{l}0.010^{* * * *} \\
(4.72)\end{array}$ \\
\hline High Pr. NOL $\times$ ETR $[0-10 \%]$ & & & $\begin{array}{l}-0.021 * * * \\
(-5.59)\end{array}$ & & & $\begin{array}{l}-0.026^{* * * *} \\
(-3.72)\end{array}$ \\
\hline Intercept & $\begin{array}{l}0.094 * * * \\
(11.57)\end{array}$ & $\begin{array}{l}0.094 * * * \\
(11.47)\end{array}$ & $\begin{array}{l}0.093 * * * \\
(11.41)\end{array}$ & $\begin{array}{l}0.079 * * * \\
(12.45)\end{array}$ & $\begin{array}{l}0.078^{* * * *} \\
(12.31)\end{array}$ & $\begin{array}{l}0.077 * * * \\
(12.21)\end{array}$ \\
\hline Industry \& Year FE & Yes & Yes & Yes & Yes & Yes & Yes \\
\hline Adj. $R^{2}$ & 0.018 & 0.020 & 0.021 & 0.024 & 0.026 & 0.026 \\
\hline $\mathrm{N}$ & 25,686 & 25,686 & 25,686 & 27,573 & 27,573 & 27,573 \\
\hline
\end{tabular}

$*, * *, * * *$ indicate that the estimated coefficient is statistically significant at the $10 \%, 5 \%$, and $1 \%$ levels, respectively, using a two-tailed test. Coefficient estimates are reported with corresponding $t$-statistics, where standard errors are clustered by firm. See Appendix A for variable definitions

may not be sustainable over multiple years. Therefore we expect that low ETRs will be more persistent for firms with large NOLs than firms without large NOLs.

To test whether large NOLs allow firms to persistently retain a low ETR, we track firms with a low ETR in year $t$ over a five-year period $(t$ to $t+4)$ and compare the persistence of low ETRs for firms with and without large NOLs. Consistent with our previous tests, we identify firms as having large NOLs at the end of year $t-1$. Table 7 reports univariate results, with Panel A showing the findings for low annual cash ETRs. $\mathrm{N}$ is equal to the low ETR observations in year $t$ that remain in the sample in the future year $t+k .^{23}$ For example, of the 11,625 Low Cash ETR 1yr observations in year $t, 7,607$ remain in the sample in year $t+1$,

\footnotetext{
$\overline{23}$ There are many reasons why firms do not remain in the sample in year $t+k$, such as having negative pretax income, an ETR outside the range of 0 to 1, being acquired, bankruptcy, etc. If a firm does not meet the requirements to stay in the sample for a given year but meets the requirements in a subsequent year, they are included in the sample in the subsequent year. For example, if a firm has negative pretax income in year $t+1$, they are not included in the sample for that year. However, if they have positive pretax income in the following year (and meet all other requirements), they are included in the sample for $t+2$.
} 
Table 11 Tax-Advantaged versus Tax-Disadvantaged Analyses

\begin{tabular}{|c|c|c|c|c|c|c|}
\hline \multirow[t]{3}{*}{ Dependent Variable: } & \multirow[b]{3}{*}{ Pr. Sign } & \multicolumn{5}{|l|}{ Delta MVA } \\
\hline & & \multicolumn{2}{|c|}{ Profit firm-years } & \multirow[b]{2}{*}{ Pr. Sign } & \multicolumn{2}{|c|}{ All firm-years } \\
\hline & & (1) & (2) & & (3) & (4) \\
\hline Deficit & $(-)$ & $\begin{array}{l}-0.181 * * * \\
(29.06)\end{array}$ & & $(+)$ & $\begin{array}{l}0.047 * * * \\
(8.31)\end{array}$ & \\
\hline High Pred. NOL & $(-)$ & & $\begin{array}{l}-0.221^{* * * *} \\
(-33.58)\end{array}$ & $(+)$ & & $\begin{array}{l}0.059 * * * \\
(9.23)\end{array}$ \\
\hline$R O A$ & & $\begin{array}{l}-0.347 * * * \\
(-11.46)\end{array}$ & $\begin{array}{l}-0.305^{* * *} \\
(-10.74)\end{array}$ & & $\begin{array}{l}-0.062 * * * \\
(-11.10)\end{array}$ & $\begin{array}{l}-0.059 * * * \\
(-10.56)\end{array}$ \\
\hline Multinational & & $\begin{array}{l}0.002 \\
(0.23)\end{array}$ & $\begin{array}{l}0.000 \\
(0.04)\end{array}$ & & $\begin{array}{l}0.006 \\
(0.97)\end{array}$ & $\begin{array}{l}0.006 \\
(0.92)\end{array}$ \\
\hline Haven & & $\begin{array}{l}-0.013 * \\
(-1.93)\end{array}$ & $\begin{array}{l}-0.008 \\
(-1.24)\end{array}$ & & $\begin{array}{l}-0.014 * * \\
(-2.27)\end{array}$ & $\begin{array}{l}-0.016^{* * *} \\
(-2.56)\end{array}$ \\
\hline Leverage & & $\begin{array}{l}-0.000 \\
(-0.03)\end{array}$ & $\begin{array}{l}-0.023 * * * \\
(-2.84)\end{array}$ & & $\begin{array}{l}0.037 * * * \\
(6.61)\end{array}$ & $\begin{array}{l}0.039 * * * \\
(7.09)\end{array}$ \\
\hline$P P E$ & & $\begin{array}{l}-0.160 * * * \\
(-11.56)\end{array}$ & $\begin{array}{l}-0.133 * * * \\
(-9.66)\end{array}$ & & $\begin{array}{l}-0.078^{* * *} * \\
(6.60)\end{array}$ & $\begin{array}{l}-0.083 * * * \\
(-7.06)\end{array}$ \\
\hline$R \& D$ & & $\begin{array}{l}-0.108^{* * *} \\
(-4.16)\end{array}$ & $\begin{array}{l}-0.095^{* * *} \\
(-3.65)\end{array}$ & & $\begin{array}{l}0.032^{* * * *} \\
(5.39)\end{array}$ & $\begin{array}{l}0.031^{* * *} \\
(5.18)\end{array}$ \\
\hline Stock Options & & $\begin{array}{l}-0.137 * \\
(1.69)\end{array}$ & $\begin{array}{l}-0.101 \\
(-1.27)\end{array}$ & & $\begin{array}{l}-0.314 * * * \\
(-6.06)\end{array}$ & $\begin{array}{l}-0.331 \text { **** } \\
(-6.38)\end{array}$ \\
\hline LnAssets & & $\begin{array}{l}-0.011^{* * *} \\
(-6.24)\end{array}$ & $\begin{array}{l}-0.011^{* * *} \\
(-5.91)\end{array}$ & & $\begin{array}{l}-0.014 * * * \\
(-9.21)\end{array}$ & $\begin{array}{l}-0.013 \text { *** } \\
(-8.28)\end{array}$ \\
\hline$M T B$ & & $\begin{array}{l}-0.000 \\
(-0.24)\end{array}$ & $\begin{array}{l}-0.000 \\
(-0.19)\end{array}$ & & $\begin{array}{l}-0.000 \\
(-0.49)\end{array}$ & $\begin{array}{l}-0.000 \\
(-0.74)\end{array}$ \\
\hline Intercept & & $\begin{array}{l}0.472 * * * \\
(19.98)\end{array}$ & $\begin{array}{l}0.443^{* * * *} \\
(18.79)\end{array}$ & & $\begin{array}{l}0.557 * * * \\
(28.05)\end{array}$ & $\begin{array}{l}0.557 * * * \\
(28.18)\end{array}$ \\
\hline Industry \& Year F.E. & & Yes & Yes & & Yes & Yes \\
\hline Adj. $R^{2}$ & & 0.071 & 0.066 & & 0.038 & 0.038 \\
\hline $\mathrm{N}$ & & 50,660 & 50,660 & & 78,353 & 78,353 \\
\hline
\end{tabular}

$*, * *, * * *$ indicate that the estimated coefficient is statistically significant at the $10 \%, 5 \%$, and $1 \%$ levels, respectively, using a two-tailed test. Coefficient estimates are reported with corresponding $t$-statistics in parentheses, where standard errors are clustered by firm. See Appendix A for variable definitions

and about $57 \%$ of them continue to retain a low ETR. Consistent with our prediction, Panel A illustrates that low ETRs are more persistent for firms with large NOLs, compared to firms without large NOLs. Specifically, about 68\% (50\%) of firms with large NOLs that had a Low Cash ETR 1yr in year $t$ continue to have a Low Cash ETR $1 y r$ in year $t+1(t+4)$, relative to only about $46 \%$ (35\%) for firms without large NOLs. Table 7 Panel B shows similar results using low annual GAAP ETRs. Namely, about $68 \%$ (34\%) of firms with 
large NOLs that had a Low GAAP ETR 1yr in year $t$ continue to have a Low GAAP ETR 1yr in year $t+1(t+4)$, relative to just $39 \%(22 \%)$ for firms without large NOLs.

In an untabulated analysis, we also examine the persistence of low ETRs for multinational and haven firms. We find that multinational (haven) firms have less persistent low ETRs compared to domestic (non-haven) firms. In particular, about $49 \%$ (35\%) of multinationals and 50\% (37\%) of haven firms that had a Low Cash ETR 1yr in year $t$ continue to have a Low Cash ETR $1 y r$ in year $t+1(t+4)$, compared to about $61 \%(46 \%)$ for domestic firms and $60 \%(45 \%)$ for non-haven firms. Similarly, about $44 \%(27 \%)$ of multinationals and $42 \%$ (24\%) of haven firms that had a Low GAAP ETR $1 y r$ in year $t$ continue to have a Low GAAP ETR $1 y r$ in year $t+1(t+4)$, compared to about $65 \%$ (32\%) for domestic firms and 64\% (33\%) for non-haven firms.

Next, we examine low ETR persistence using multivariate regressions that control for other tax positions. To perform these analyses, we employ the regression model outlined in Eq. (1) and estimate regressions for years $t+1$ to $t+4$. Table 8 Panel A reports the results for low annual cash ETRs. Consistent with our prediction, we find that firms with large NOLs have a significantly higher probability of retaining a Low Cash ETR 1yr in future years, relative to firms without large NOLs. Panel B of Table 8 reports similar results for low annual GAAP ETRs. However, we do not find that firms with large NOLs have a higher probability of retaining a Low GAAP ETR $1 y r$ in year $t$ +3 and $t+4$, suggesting that large NOL firms release the valuation allowance gradually over the first couple of years (i.e., $t$ to $t+1$ ) and then release the full amount in year $t+2 .{ }^{24}$ Further, in untabulated results, we find that multinational (haven) firms are less likely to achieve persistently low ETRs than domestic (non-haven) firms. Taken together, the results in Section 3 and Tables 7 and 8 provide evidence that not only do large NOLs allow firms to attain a low ETR, they also allow them to persistently retain a low ETR into the near future.

\subsection{Low ETRs and tax risk}

In this subsection, we directly examine whether low ETR firms incur tax risk. Given our finding that the majority of low ETR firms are primarily benefiting from large NOLs and that these large NOLs allow firms to persistently retain a low ETR, we predict that low ETR firms do not incur significant tax risk. To test this prediction, we estimate the following OLS regression.

$$
\begin{aligned}
\operatorname{Tax}_{\text {Risk }}= & \beta_{0}+\beta_{1} \text { ETR } 0-10 \%_{\mathrm{it}}+\beta_{2} \text { ETR 10-20\% } \%_{\mathrm{it}}+\beta_{3} \text { ETR 20-30\% } \%_{\mathrm{it}} \\
& +\beta_{4} \text { ETR } 40-100 \%_{\mathrm{it}}+\varepsilon_{\mathrm{it}}
\end{aligned}
$$

\footnotetext{
${ }^{24}$ This explanation is consistent with guidance provided by accounting firms, which advises that firms need to show multiple years of profits before fully releasing the valuation allowance. For example, EY's firm guidance states: "when an entity has experienced an uncertain operating environment characterized by a period of recurring losses, it will not be unusual that a demonstrated ability to operate profitably for a recurring annual period as well as evidence of a more stable operating environment will generally be needed" before releasing the full valuation allowance (emphasis added, EY. 2020, p. 166). Manuals for the other large public accounting firms contain similar guidance (see PWC 2019, pp. 5-7; KPMG 2019, pp. 151 and 186; Deloitte 2018, p. 177).
} 
The dependent variable, Tax Risk, represents either (1) the firm's current year additions in UTBs (UTB Additions) or (2) the firm's future five-year cash ETR volatility (Future Cash ETR Volatility), where higher levels of both measures suggest greater tax risk. Similar to Dyreng et al. (2019), we use UTB additions, rather than the level of UTBs, because we are interested in current year positions as opposed to historical positions, which may have been taken before the firm was in its current ETR group. Note that additions to UTBs and future cash ETR volatility capture different aspects of tax risk. For instance, while UTBs reflect managers' and external auditors' assessment about the sustainability of tax positions (i.e., ex ante tax risk), future tax rate volatility captures the dispersion of actual tax outcomes (i.e., ex post tax risk).

Similar to our distribution analysis, the independent variables divide the firms into five groups based on their annual cash or GAAP ETRs. ETR $0-10 \%$ is an indicator variable equal to one if the firm has an ETR between 0 and $10 \%$ in the current year and zero otherwise, and we create analogous indicator variables for the $10 \%$ to $20 \%, 20 \%$ to $30 \%$, and $40 \%$ to $100 \%$ groups. We use the $30 \%$ to $40 \%$ group as the baseline group for our regressions. We view this group as the appropriate baseline, because these firms pay roughly the statutory tax rate and thus represent a relatively risk-free group that are not likely to be engaging in high levels of aggressive tax planning. ${ }^{25}$ The benefit of dividing the firms into ETR groups is that it allows us to provide new insights about how tax risk is manifest across the ETR distribution, and allows for an easy comparison between the groups. ETR 0-10\% is the variable of interest and captures whether low ETR firms incur more or less tax risk relative to firms that pay roughly the statutory tax rate. In addition to the base regression presented in Eq. (2), we estimate a modified version that examines how the relation between low ETRs and tax risk varies across firms with and without large NOLs. To do so, we interact ETR 0-10\% with our proxies for large NOLs.

The results using our first measure of tax risk, UTB Additions, are presented in Table 9. ${ }^{26}$ Columns (1)-(3) and (4)-(6) report results where the ETR groups are formed using annual cash and GAAP ETRs, respectively. We find that low ETR firms do not incur significant tax risk. Specifically, columns (1) and (4) demonstrate that firms with ETRs between 0 to $10 \%$ accrue UTBs at a similar rate as firms that pay roughly the statutory tax rate (i.e., the baseline group with ETRs of $30 \%$ to $40 \%$ ). This finding contrasts with the inference of Dyreng et al. (2019) that firms with relatively lower ETRs bear significantly greater tax risk than firms with higher ETRs.

To reconcile the seemingly opposing results, note that columns (1) and (4) also demonstrate there is a nonlinear relation between ETRs and UTB additions. For instance, while firms with the lowest ETRs incur similar additions in UTBs as firms that pay roughly the statutory tax rate, firms with ETRs between $10 \%$ to $20 \%$ recognize the highest UTB additions. Since Dyreng et al. (2019) classify firms as "tax avoiders" if their ETR is in the bottom tercile, their classification includes almost all of the firms in both the 0 to $10 \%$ and the $10 \%$ to $20 \%$ groups. To examine how this different classification affects our results, in an untabulated analysis, we combine the 0 to $10 \%$ and $10 \%$ to $20 \%$ groups and create an ETR 0-20\% variable. Consistent with Dyreng et al. (2019), we find a positive and significant

\footnotetext{
${ }^{25}$ During our sample period, the U.S. federal tax rate was $35 \%$, and prior research estimates the average state tax rate for a large sample of U.S. firms is about $4 \%$ (Shevlin et al. 2017).

${ }^{26}$ As we are interested in the tax risk of profitable companies, we eliminate observations where pretax income is negative, consistent with our other tests.
} 
association between ETR 0-20\% and UTB Additions. This illustrates that since the relation between ETRs and UTB additions varies across the ETR distribution, inferences will change depending on how the model is specified. ${ }^{27}$

Columns (2)-(3) and (5)-(6) of Table 9 show the results once we interact ETR 0-10\% with our proxies for large NOLs. In all columns, we find that the interaction term is negative and significant suggesting that, relative to firms without large NOLs in the 0 to $10 \%$ group, firms with large NOLs in this low ETR group have lower UTB additions. We also find that ETR 0-10\% (i.e., the main effect) becomes positive and significant, suggesting that firms without large NOLs that achieve a low ETR do incur significant tax risk (e.g., multinational and haven firms). ${ }^{28}$

The results using our second measure of tax risk, Future Cash ETR Volatility, are presented in Table 10. Columns (1)-(3) and (4)-(6) report results where the ETR groups are formed using annual cash and GAAP ETRs, respectively. We again find that low ETR firms do not incur significant tax risk. Specifically, columns (1) and (4) demonstrate that firms with ETRs between 0 to $10 \%$ do not have higher future tax rate volatility than firms that pay roughly the statutory tax rate (i.e., the baseline group with ETRs of $30 \%$ to $40 \%$ ). The results in columns (1) and (4) also expand on the findings in Guenther et al. (2017) by illustrating there is a nonlinear relation between ETRs and future tax rate volatility. In particular, while firms with the lowest ETRs have similar volatility as firms that pay roughly the statutory tax rate, firms with ETRs between $40 \%$ to $100 \%$ incur the highest volatility, which likely reflects the effects of transitory items, rather than aggressive tax planning (Schwab et al. 2020).

Columns (2)-(3) and (5)-(6) show the results once we interact ETR 0-10\% with our proxies for large NOLs. In all columns, we find that the interaction term is negative and significant suggesting that, relative to firms without large NOLs in the 0 to $10 \%$ group, firms with large NOLs have lower future tax rate volatility. In columns (2)-(3) but not (5)-(6), we also find that ETR $0-10 \%$ becomes positive, suggesting that firms without large NOLs that achieve a low cash ETR do have higher future tax rate volatility.

Taken together, the findings in Tables 9 and 10 tell a consistent story: on average, firms with ETRs between 0 to $10 \%$ (i.e., low ETR firms) do not incur significant tax risk. Further, by dividing the firms into ETR groups, we shed light on the seemingly opposing results of Dyreng et al. (2019) and Guenther et al. (2017). Specifically, we show that, since the relation between ETRs and tax risk is nonlinear, inferences will change depending on how the model is specified. We also note that, since UTBs capture ex ante tax risk while future tax rate volatility captures ex post risk, there can be differences between the measures in how tax risk is manifest across the ETR distribution.

\footnotetext{
${ }^{27}$ We also replicate Model 1 from Table 4 of Dyreng et al. (2019) and continue to find the effect of nonlinearities. That is, the coefficient on ETR $0-20 \%$ is positive and significant, but when we separate it into two groups, ETR $0-10 \%$ is insignificant, and ETR $10-20 \%$ is positive and significant.

${ }^{28}$ For example, in untabulated analyses, if we take the model in column (2) and add an interaction term of ETR 0 $-10 \% \times$ Multinational (or $\times$ Haven), the main effect on ETR [0-10\%] becomes statistically insignificant again, and the interaction term of ETR $0-10 \% \times$ Multinational is positive and statistically significant. Furthermore, the interaction term of ETR $0-10 \% \times$ Deficit continues to be negative and statistically significant.
} 


\section{Are firms with large NOLs tax-advantaged or tax-disadvantaged?}

The results presented in Sections 3 and 4 suggest that large NOLs allow firms to attain low ETRs in profit years without incurring tax risk. Thus firms with large NOLs appear to have a tax advantage over other profitable firms. At face value, some might see this as evidence that NOLs represent a loophole that policymakers should close. However, we predict that firms with large NOLs are actually taxdisadvantaged when both profit and loss years are considered. We base this prediction on the notion that, if a firm can fully utilize all of its NOLs, the NOLs will at best allow the firm to be tax neutral. This is because, in the best-case scenario, the tax refunds the firm was unable to claim during loss years should eventually equal the tax savings the firm will get in profit years (ignoring the time value of money) when it is able to exactly offset future profits with past losses. However, if the NOLs are not fully utilized, which we expect to sometimes be the case, firms with large NOLs will, on average, be tax-disadvantaged.

To test this expectation, we use the measure developed by Henry and Sansing (2018), Delta MVA, as our dependent variable in a sample of profit and loss years. (See Appendix A for more details on how Delta MVA is calculated.) As reported in Table 11, we find that our proxies for large NOLs are negatively associated with Delta MVA during profit years, suggesting that, relative to other profitable firms, firms with large NOLs are tax-advantaged in profitable years. However, when we include both profit and loss years in the sample, our proxies for large NOLs are positively associated with Delta MVA, consistent with our expectation that firms with large NOLs are tax-disadvantaged overall.

\section{Conclusion}

We examine how most profitable firms attain low ETRs (i.e., an ETR between 0 and $10 \%)$. The business press, public interest groups, policymakers, and academics are interested in firms with the lowest ETRs. Yet we argue that little is known about this group of firms. That is, while there is an extensive literature on cross-sectional differences in ETRs, studies generally focus on average ETRs and thus cannot directly speak to how a firm ends up in the left-tail of the distribution.

While it is often assumed that low ETR firms are engaging in aggressive tax planning, we predict that the majority are primarily benefiting from a benign tax position: large NOLs. Testing this prediction requires reliable measures that identify whether firms have large NOLs. To overcome the severe measurement error in Compustat NOL data, we use an intuitive proxy for large NOLs based on whether a firm reports an accumulated deficit on its balance sheet (i.e., negative retained earnings). We also corroborate our results using another proxy for large NOLs based on the predicted NOL benefit constructed by Heitzman and Lester (2020).

Using these measures, we demonstrate the majority of firms with low ETRs suffered heavy losses in the past and are now utilizing large NOLs. We also find that large NOLs allow firms to persistently retain low ETRs year after year. In contrast, we find that multinationals and tax haven firms, which are often assumed to have more opportunities for aggressive tax planning, have a lower probability of attaining a low 
ETR relative to domestic and non-haven firms. Collectively, these findings suggest that the typical low ETR firm does not incur significant tax risk. Consistent with this, we find that low ETR firms accrue unrecognized tax benefits at a similar rate as firms that pay the statutory tax rate and do not experience higher future tax rate volatility. Overall, the results shed light on the profile of the average low ETR firm and provide evidence that the majority are utilizing large NOLs rather than aggressive tax planning.

Our study also has implications for future researchers who want to study or control for large NOLs. In particular, our deficit measure, along with the predicted NOL benefit calculated by Heitzman and Lester (2020), provide two solutions for future researchers, depending on their research question. That is, our deficit measure, which is a component of the predicted NOL benefit, appears to be a parsimonious version of the predicted NOL benefit in terms of identifying firms with large NOLs, while the predicted NOL benefit will better capture the full distribution of NOLs.

Supplementary Information The online version contains supplementary material available at https://doi.org/ 10.1007/s11142-021-09614-8.

\section{Appendix A Variable Definitions}

\footnotetext{
Variable Name Description

Dependent Variables

Low Cash ETR 1yr Indicator variable equal to one if Cash ETR $1 y r$ falls between 0 and $10 \%$, zero otherwise. The underlying Cash ETR $1 y r$ is calculated as cash taxes paid (TXPD) divided by pretax income (PI). Firm-years with negative denominators and/or Cash ETR $1 y r$ outside the range $[0,1]$ are set to missing.

Low Cash ETR 3yr Indicator variable equal to one if Cash ETR $3 y r$ falls between 0 and $10 \%$, zero otherwise. The underlying Cash ETR $3 y r$ is calculated as the three-year sum (from year $t$ to $t+2$ ) of cash taxes paid (TXPD) divided by the three-year sum of pretax income (PI). Observations where the three-year sum of pretax income is negative and/or Cash ETR $3 y r$ is outside the range [0,1] are set to missing.

Low Cash ETR 5yr Indicator variable equal to one if Cash ETR $5 y$ r falls between 0 and $10 \%$, zero otherwise. The underlying Cash ETR 5yr is calculated as the five-year sum (from year $t$ to $t+4$ ) of cash taxes paid (TXPD) divided by the five-year sum of pretax income (PI). Observations where the five-year sum of pretax income is negative and/or Cash ETR $5 y r$ is outside the range [0,1] are set to missing.

Low GAAP ETR 1yr Indicator variable equal to one if GAAP ETR $1 y r$ falls between 0 and $10 \%$, zero otherwise. The underlying GAAP ETR $1 y r$ is calculated as total tax expense (TXT) divided by pretax income (PI). Firm-years with negative denominators and/or an ETR outside the range $[0,1]$ are set to missing.

Cash ETR 1yr

Cash taxes paid (TXPD) divided by pretax income (PI). Firms are required to have a positive denominator and Cash ETR $1 y r$ is truncated to the range [0,1].

GAAP ETR 1yr

$\operatorname{ETR}(X 0 \%, X 0 \%]$

Total tax expense (TXT) divided by pretax income (PI). Firms are required to have a positive denominator, and GAAP ETR $1 y r$ is truncated to the range [0,1].

Indicator variable equal to one if the firm's ETR falls within a particular ETR range (e.g., $20 \%$ to $30 \%$ ), zero otherwise.
} 


\begin{tabular}{|c|c|}
\hline Variable Name & Description \\
\hline UTB Additions & $\begin{array}{l}\text { Increase in uncertain tax benefit, measured as the increase in current year uncertain tax } \\
\text { positions (TXTUBPOSINC) scaled by sales (SALE). Multiplied by } 100 \text { for } \\
\text { readability. }\end{array}$ \\
\hline $\begin{array}{l}\text { Future Cash ETR } \\
\quad \text { Volatility }\end{array}$ & $\begin{array}{l}\text { The standard deviation of Cash ETR } 1 y r \text { over a five-year period (t+1 to } t+5) \text {. } \\
\text { Individual years where Cash ETR } 1 y r \text { does not have a positive denominator and/or } \\
\text { it is outside the range of }[0,1] \text { are not included in this calculation. }\end{array}$ \\
\hline Delta $M V A$ & $\begin{array}{l}\text { Cash taxes paid (TXPD) minus the change in tax refund receivable (TXR) minus the } \\
\text { product of pretax income times the statutory tax rate }(\mathrm{PI} \times 0.35) \text {, all scaled by the } \\
\text { market value of assets (AT }+((\mathrm{PRCC} F \times \mathrm{CSHO})-\mathrm{SEQ}) \text {. If the market value of assets } \\
\text { is missing, the book value of assets (AT) is instead used as the deflator. }\end{array}$ \\
\hline
\end{tabular}

Variables of Interest

Deficit

Indicator variable equal to one in year $t$ if the firm reported an accumulated deficit (i.e., negative value for its retained earnings: REUNA) at the end of the prior year, zero otherwise.

High Pred. NOL Indicator variable equal to one in year $t$ if the firm's predicted NOL is in the top quartile at the end of the prior year, zero otherwise. Predicted NOLs are calculated following Heitzman and Lester (2020). For additional details on this calculation, see Appendix B.

\section{Control Variables}

$R O A$

Return on assets, measured as pretax income (PI) less extraordinary items (XI), all scaled by lagged total assets (AT).

Multinational

Indicator variable equal to one if the firm has nonzero pretax foreign income (PIFO), zero otherwise.

Haven

Indicator variable equal to one if the firm has a subsidiary in a tax haven country per Exhibit 21, zero otherwise.

Leverage $\quad$ Leverage, measured as long-term debt (DLC + DLTT) scaled by lagged total assets (AT). Set DLC and DLTT to zero if missing.

$P P E$

Property, plant, and equipment, measured as net PP\&E (PPENT) scaled by lagged total assets (AT).

$R \& D \quad$ Research and development expense (XRD) scaled by Sales (SALE). Set XRD to zero if missing.

Stock Options $\quad$ Stock options, measured as stock option expense (STKCO) divided by lagged total assets (AT). For fiscal years that ended prior to when SFAS 123R went into effect (June 15, 2005), we instead use the implied stock option expense (XINTOPT) in place of STKCO. Set to zero if missing.

LnAssets The natural log of total assets (AT).

MTB

Market to book ratio, at the beginning of the year, measured as market value of equity (PRCC_F $\times$ CSHO) scaled by book value of equity (CEQ).

Industry Fixed Effects Indicator variables for each of the Fama French 48 industries.

\section{Appendix B Calculation of Predicted NOL}

This appendix outlines how Predicted NOL is calculated, following Heitzman and Lester (2020). In their paper, Heitzman and Lester hand collect NOL data from the 10$\mathrm{K}$ filings of ExecuComp companies over the years 2010 to 2015. Using this data, they construct a NOL benefit variable, which is measured as tax-rate weighted NOL divided 
by total assets. They then use Compustat data to predict this hand collected variable, as reported in their Table 4 columns (4) and (5). We calculate Predicted NOL based on the coefficient estimates from those regressions. When Compustat NOL data is available (i.e., TLCF > 0), Predicted NOL is calculated as follows.

Predicted_NOL $=0.009+(0.185 \times$ Compustat_TLCF $)+(-0.013 \times$ Sum_PTI_3yr $)+$ $\left(0.008 \times N e g \_S u m \_P T I \_3 y r\right)+(0.012 \times$ Retained_Earn $)+(0.003 \times$ Tax_Paid $)+$ $(0.002 \times$ Foreign_Activity $)+(-0.006 \times R D)+(0.002 \times$ Market_To_Book $)$

$+(-0.001 \times$ LnBookAssets $)+(-0.013 \times$ Sum_Acquisitions_3yr $)+(0.007 \times$ Leverage $)$.

When Compustat NOL data are not available, Predicted NOL is calculated as follows.

Predicted_NOL $=0.024+(-0.044 \times$ Sum_PTI_3yr $)+\left(0.027 \times N e g \_S u m \_P T I \_3 y r\right)$

$+(0.035 \times$ Retained_Earn $)+(0.012 \times$ Tax_Paid $)+(0.008 \times$ Foreign_Activity $)$

$+(0.074 \times R D)+(0.004 \times$ Market_To_Book $)+(-0.002 \times$ LnBookAssets $)+$

$(-0.026 \times$ Sum_Acquisitions_3yr $)+(-0.002 \times$ Leverage $)$,

where each of the variable inputs to these equations are calculated as follows. Compustat_TLCF equals net operating loss carryforwards (TLCF) divided by total assets (AT). Sum_PTI_3yr equals the sum of pretax income (PI) over the years $t$ to $t-2$ minus the sum of special items (SPI) over the years $t$ to $t-2$, all divided by total assets (AT). If special items is missing, it is set to zero. Neg_Sum_PTI_3yr is an indicator set to one if Sum_PTI_3yr is less than zero and set to zero otherwise. Retained_Earn is an indicator set to one if retained earnings (RE) is less than zero and set to zero otherwise. Tax_Paid is an indicator set to one if cash taxes paid (TXPD) is less than or equal to zero and set to zero otherwise. Foreign_Activity is an indicator set to one if the firm reports nonzero pretax foreign income (PIFO) or foreign taxes (TXDFO or TXFO) and set to zero otherwise. $R D$ equals research and development expense (XRD) scaled by sales (SALE). It is set to zero if XRD is missing. Market_To_Book equals total assets (AT) minus common equity (CEQ) plus the market value of equity (PRCC_F*CSHO), all scaled by total assets (AT). LnBookAssets equals the natural log of total assets (AT). Sum_Acquisitions_3yr equals the sum of cash (AQC) and stock acquisitions $(\mathrm{ACQCSHI} \times 0.5 \times($ ending price + beginning price $) / 2$ ) over the years $t$ to $t-2$, all scaled by beginning total assets (AT). Leverage equals total long-term debt (DLTT+DLC) divided by total assets (AT).

Acknowledgements This paper has benefited from helpful comments and suggestions from Jennifer Blouin (editor), an anonymous reviewer, Brad Badertscher, Erik Beardsley, Jenny Brown, Andy Call, Mike Drake, Yonca Ertimur, Dave Guenther, Michelle Harding (discussant), Jeff Hoopes, Michal Matejka, Brian Spilker, Jake Thornock, John Treu, Hal White, Brady Williams, Brian Williams, Ryan Wilson, and workshop participants at Arizona State University, University of Notre Dame, the Universities of British Columbia, Oregon, and Washington (UBCOW) conference, the 2017 Brigham Young University Accounting Research Symposium, and the 2018 AAA Annual Meeting. We also gratefully acknowledge the financial support from our respective institutions.

\section{References}

Altman, E.I. (1968). Financial ratios, discriminant analysis and the prediction of corporate bankruptcy. Journal of Finance. 23 (4): 589-609. 
Badertscher, B.A., J.D. Phillips, M. Pincus, and S. Rego. (2009). Earnings management strategies and the trade-off between tax benefits and detection risk: To conform or not to conform? The Accounting Review. 84 (1): 63-97.

Balakrishnan, K., J. Blouin, and W. Guay. (2019). Tax aggressiveness and corporate transparency. The Accounting Review. 94 (1): 45-69.

Blouin, J. (2014). Defining and measuring tax planning aggressiveness. National Tax Journal. 67 (4): 875899.

Blouin, J., and L. Robinson. (2020). Double counting accounting: How much profit of multinational enterprises is really in tax havens? University of Pennsylvania working paper.

Chen, S., X. Chen, Q. Cheng, and T. Shevlin. (2010). Are family firms more tax aggressive than non-family firms? Journal of Financial Economics. 95 (1): 41-61.

Chew, J. (2016). 7 corporate giants accused of evading billions in taxes. Fortune. Available at: http://fortune. com/2016/03/11/apple-google-taxes-eu/

Christensen, D. (2016). Corporate accountability reporting and high-profile misconduct. The Accounting Review. 91 (2): 377-399.

Chyz, J., W. Leung, O.Z. Li, and O. Rui. (2013). Labor unions and tax aggressiveness. Journal of Financial Economics. 108 (3): 675-698.

Cooper, M., and M. Knittel. (2006). Partial loss Refundability: How are corporate tax losses used? National Tax Journal. 59 (3): 651-663.

De Simone, L., L. Mills, and B. Stomberg. (2019). Using IRS data to identify income shifting to foreign affiliates. Review of Accounting Studies. 24 (2): 694-730.

Deloitte. (2018). A roadmap to accounting for income taxes. Available at: https://www2.deloitte.com/us/en/ pages/tax/articles/a-roadmap-for-accounting-for-income-taxes.html

Desai, M.A., and D. Dharmapala. (2006). Corporate tax avoidance and high-powered incentives. Journal of Financial Economics. 79 (1): 145-179.

Donohoe, M., and R. Knechel. (2014). Does corporate tax aggressiveness influence audit pricing? Contemporary Accounting Research. 31 (1): 284-308.

Drake, K., R. Hamilton, and S. Lusch. (2020). Are declining effective tax rates indicative of tax avoidance? Insight from effective tax rate reconciliations. Journal of Accounting and Economics. 70 (1): 101317.

Drucker, J. (2010). Google 2.4\% rate shows how $\$ 60$ billion lost to tax loopholes. Bloomberg News.

Drucker, J. and S. Bowers. (2017). After a tax crackdown, apple found a new shelter for its Profits. New York Times. Available at: https://nyti.ms/2hMV2Gw

Dyreng, S., M. Hanlon, and E. Maydew. (2008). Long-run corporate tax avoidance. The Accounting Review. 83 (1): $61-82$.

Dyreng, S., M. Hanlon, and E. Maydew. (2019). When does tax avoidance result in tax uncertainty? The Accounting Review. 94 (2): 179-203.

Dyreng, S., M. Hanlon, E. Maydew, and J. Thornock. (2017). Changes in corporate effective tax rates over the past 25 years. Journal of Financial Economics. 124 (3): 441-463.

Dyreng, S., and B. Lindsey. (2009). Using financial accounting data to examine the effect of foreign operations located in tax havens and other countries on US multinational firms ' tax rates. Journal of Accounting Research. 47 (5): 1283-1316.

Economist. (2013). Company taxation. The Price Isn’t Right. The Economist. Feb. 16.

Economist. (2018). Stuck in the past: Overhaul tax for the 21st century. The Economist. Aug. 9.

EY. (2020). Financial reporting developments: A comprehensive guide. Income taxes. Available at: https:// assets.ey.com/content/dam/ey-sites/ey-com/en_us/topics/assurance/accountinglink/ey-frdbb1150-11-192020-v2.pdf

Gardner, M., R. McIntyre, and R. Phillips. (2017). The 35 percent corporate tax myth: Corporate tax avoidance by fortune 500 companies, 2008 to 2015. Institute on taxation and economic policy, Washington, DC.

Graham, J., M. Hanlon, T. Shevlin, and N. Shroff. (2014). Incentives for tax planning and avoidance: Evidence from the field. The Accounting Review. 89 (3): 991-1023.

Gravelle, J. (2015). Tax havens: International tax avoidance and evasion. Congressional Research Service Report.

Guenther, D., S. Matsunaga, and B. Williams. (2017). Is tax avoidance related to firm risk? The Accounting Review. 92 (1): 115-136.

Guenther, D., R. Wilson, and K. Wu. (2019). Tax uncertainty and incremental tax avoidance. The Accounting Review. 94 (2): 229-247.

Hanlon, M., and S. Heitzman. (2010). A review of tax research. Journal of Accounting and Economics. 50 (2): $127-178$. 
Hanlon, M., and J. Hoopes. (2014). What do firms do when dividend tax rates change? An examination of alternative payout responses. Journal of Financial Economics. 114 (1): 105-124.

Hasan, I., C. Hoi, Q. Wu, and H. Zhang. (2014). Beauty is in the eye of the beholder: The effect of corporate tax avoidance on the cost of bank loans. Journal of Financial Economics. 113 (1): 109-130.

Henry, E., and R. Sansing. (2018). Corporate tax avoidance: Data truncation and loss firms. Review of Accounting Studies. 23 (3): 1042-1070.

Heitzman, S., and R. Lester. (2020). Tax Loss Measurement. University of Southern California and Stanford University working paper.

Hoopes, J., D. Mescall, and J. Pittman. (2012). Do IRS audits deter corporate tax avoidance? The Accounting Review. 87 (5): 1603-1639.

KPMG. (2019). Accounting for income taxes handbook. Available at: https://frv.kpmg.us/reference-library/ 2021/accounting-for-income-taxes.html

Joint Committee on Taxation. (2010). Present law and background related to possible income shifting and transfer pricing. JCX-37-10, July 20, available at: www.jct.gov

Kim, J., Y. Li, and L. Zhang. (2011). Corporate tax avoidance and stock price crash risk: Firm-level analysis. Journal of Financial Economics. 100 (3): 639-662.

Kinney, M., and E. Swanson. (1993). The accuracy and adequacy of tax data in Compustat. Journal of the American Taxation Association. 15 (1): 121-135.

Levin, C. and J. McCain. (2013). Subcommittee to examine offshore profit shifting and tax avoidance by apple. May 13. Available at: https:/www.hsgac.senate.gov/imo/media/doc/PRESS\%20RELEASE\% 20on\%20offshore\%20profit\%20shifting\%20hearing\%20(Apple)\%205-20-13.pdf

Lisowsky, P., L. Robinson, and A. Schmidt. (2013). Do publicly disclosed tax reserves tell us about privately disclosed tax shelter activity? Journal of Accounting Research. 51 (3): 583-629.

Mills, L., K. Newberry, and G. Novack. (2003). How well do Compustat NOL data identify firms with US tax return loss carryovers? Journal of the American Taxation Association. 25 (2): 1-17.

Phillips, R., M. Gardner, A. Robbins, and M. Surka. (2017). Offshore shell games 2017: The use of offshore tax havens by fortune 500 companies. Institute on taxation and economic policy. Washington.

PWC. (2019). Income taxes. Available at: https://viewpoint.pwc.com/dt/us/en/pwc/accounting_guides/ income_taxes/income_taxes_16_US/chapter_1_scope_of_a_US/11_chapter_overview_7_US.html

Rego, S. (2003). Tax-avoidance activities of US multinational corporations. Contemporary Accounting Research. 20 (4): 805-833.

Rego, S., and R. Wilson. (2012). Equity risk incentives and corporate tax aggressiveness. Journal of Accounting Research. 50 (3): 775-810.

Sanders, B. (2016). Many profitable corporations pay zero Federal Income Taxes, GAO Finds. Available at: https://www.sanders.senate.gov/press-releases/many-profitable-corporations-pay-zero-federal-incometaxes-gao-finds/

Scholes, M., M. Wolfson, M. Erickson, M. Hanlon, E. Maydew, and T. Shevlin. (2015). Taxes and business strategy: A planning approach. fifth ed. Pearson Prentice Hall.

Schwab, C., B. Stomberg, and J. Xia. (2020). How well do effective tax rates capture tax avoidance? University of North.

Shevlin, T., J. Thornock, and B. Williams. (2017). An examination of firms' responses to tax forgiveness. Review of Accounting Studies. 22 (2): 577-607.

Torry, H. (2014). More than 50 countries sign tax Deal. Wall street journal online. Available at: https://www. wsj.com/articles/fifty-countries-to-sign-tax-deal-1414577992

Treasury Inspector General for Tax Administration. (2015). The internal revenue service administered corporate net operating losses efficiently and effectively; however, financial reporting could be improved. October 13, Reference No. 2016-IE-R002.

U.S. Government Accountability Office (GAO). (2016). Most large profitable U.S. corporations paid tax but effective tax rates differed significantly from the statutory rate. Publication No. GAO-16-363.

Publisher's note Springer Nature remains neutral with regard to jurisdictional claims in published maps and institutional affiliations. 


\section{Affiliations}

Dane M. Christensen ${ }^{1} \cdot$ David G. Kenchington ${ }^{2} \cdot$ Rick C. Laux ${ }^{3}$

1 University of Oregon, Eugene, OR 97403, USA

2 Arizona State University, Tempe, AZ 85287, USA

3 Purdue University, West Lafayette, IN 47907, USA 